\title{
Geochemical Properties and Saline-Water Intrusion in the Valle de Yabucoa Alluvial Aquifer, Southeastern Puerto Rico
}

By Joseph W. Troester and Ronald T. Richards

U.S. GEOLOGICAL SURVEY

Water-Resources Investigations Report 96-4188

Prepared in cooperation with the

PUERTO RICO AQUEDUCT AND SEWER AUTHORITY and

PUERTO RICO INDUSTRIAL DEVELOPMENT COMPANY 


\section{U.S. DEPARTMENT OF THE INTERIOR BRUCE BABBITT, Secretary}

\section{U.S. GEOLOGICAL SURVEY}

Gordon P. Eaton, Director

Use of trade names in this report is for identification purposes only and does not imply endorsement by the U.S. Government.

For additional information write to:

Copies of this report can be purchased from:

District Chief

U.S. Geological Survey

GSA Center, Suite 400-15

U.S. Geological Survey

651 Federal Drive

Branch of Information Services

San Juan, Puerto Rico 00965

Box 25286

Denver, CO 80225-0286 


\section{CONTENTS}

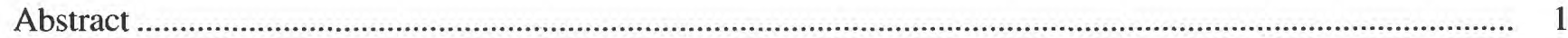

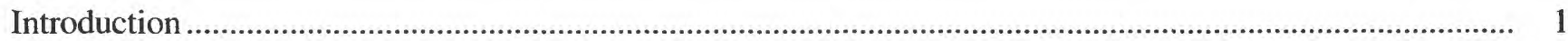

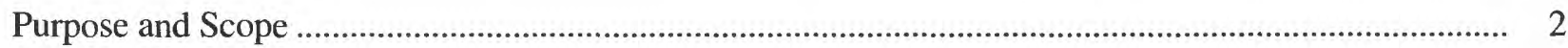

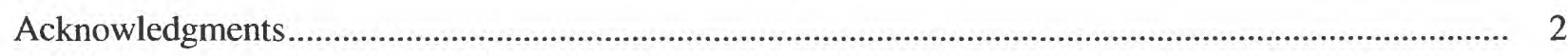

Geology, Climate, and Geomorphology of the Valle de Yabucoa............................................................... 2

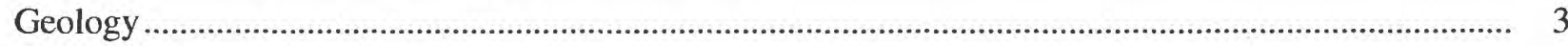

San Lorenzo Batholith ................................................................................................................

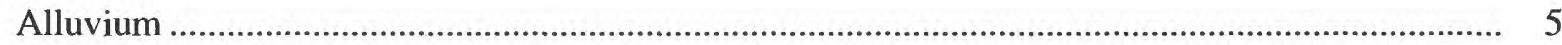

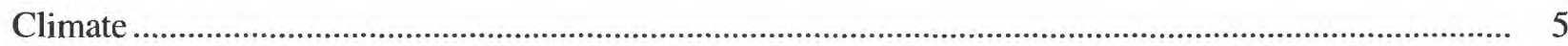

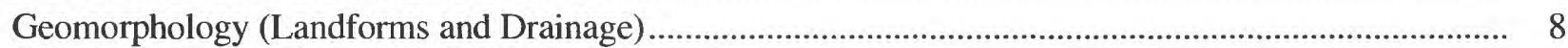

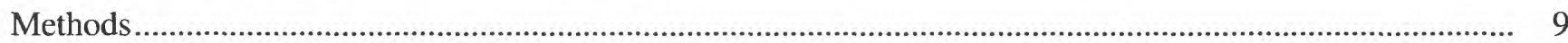

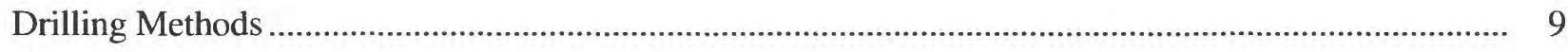

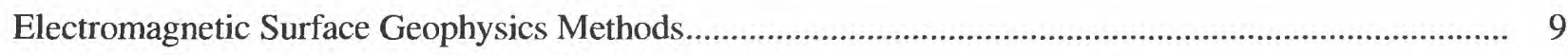

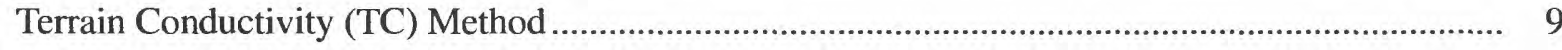

Transient Electromagnetic (TEM) Method ........................................................................... 10

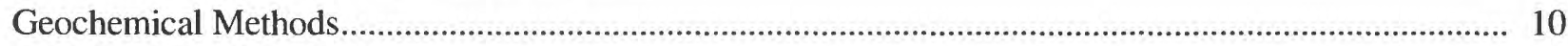

Hydrogeology of the Valle de Yabucoa Alluvial Aquifer ...................................................................... 11

Water Use From the Valle de Yabucoa Alluvial Aquifer ....................................................................... 18

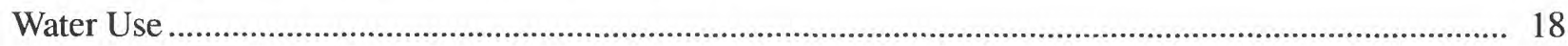

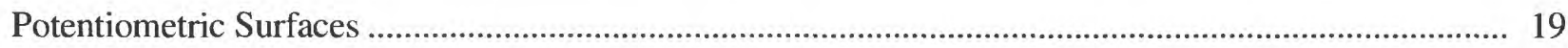

Geochemistry of the Valle de Yabucoa Alluvial Aquifer..................................................................... 23

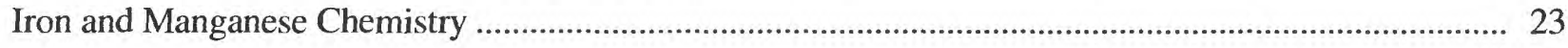

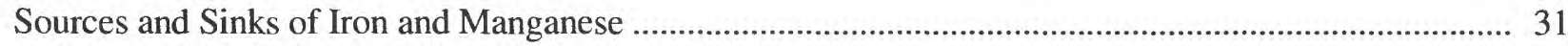

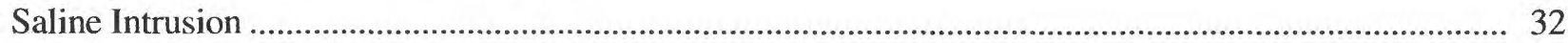

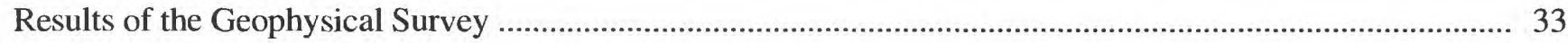

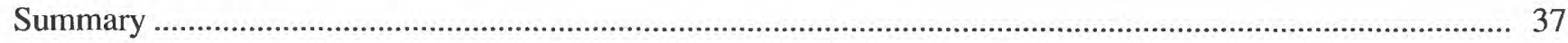

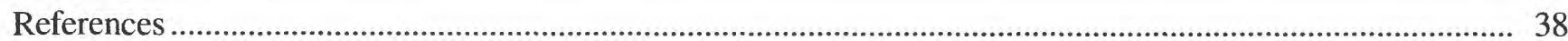




\section{FIGURES}

1. Map showing location of the Valle de Yabucoa, Puerto Rico, the boundary of the alluvial valley fill, major streams, and cultural features

2. Graph showing precipitation histogram of the average monthly precipitation at the Central Roig, Yabucoa, Puerto Rico

3. Map showing pre-development potentiometric-surface map of the Valle de Yabucoa, Puerto Rico

4. Map showing locations of selected wells in the Valle de Yabucoa, Puerto Rico

5. Graphs showing pumping rate at the refinery and water levels in the Valle de Yabucoa alluvial aquifer in southeastern Puerto Rico

6. Map showing potentiometric-surface map of the Valle de Yabucoa alluvial aquifer, Puerto Rico, July 1990.

7. Map showing location of the stream sites at which discharge measurement were made on July 5, 1990, in the Valle de Yabucoa, Puerto Rico

8. Diagram showing Eh-pH stability for ferromagnesian oxides showing the Eh and $\mathrm{pH}$ of 15 ground-water samples from the Valle de Yabucoa alluvial aquifer, Puerto Rico.

9. Graphs showing distribution of iron and manganese concentrations in water pumped from (A) abandoned and small private wells and from (B) high-production industrial and public-supply wells.

10. Map showing distribution of iron in water in the Valle de Yabucoa alluvial aquifer, Puerto Rico.

11. Map showing distribution of manganese in water in the Valle de Yabucoa alluvial aquifer, Puerto Rico.

12. Piper diagram showing overall composition of sampled water in the Valle de Yabucoa alluvial aquifer, Puerto Rico.

13. Map showing apparent conductivity data from the TC method using a 40-m coil separation and a horizontal dipole $(\mathrm{H} 40)$ in the Valle de Yabucoa, Puerto Rico.

14. Map showing the altitude of the top of bedrock in the Valle de Yabucoa, Puerto Rico

15. Map showing the altitude of the top of bedrock in the Valle de Yabucoa, Puerto Rico based on the drilling data available in 1970 .

\section{TABLES}

1. Minimum, maximum, and average chemical concentrations for the 22 stream sediment samples in the Yabucoa and Punta Guayanés quadrangles from Marsh (1992a, b) 
2. Annual precipitation, average temperature, and annual pan evaporation for the National Oceanic and Atmospheric Administration weather station at Central Roig, in Yabucoa, Puerto Rico.

3. Description of selected wells completed in the Valle de Yabucoa alluvial aquifer, Puerto Rico

4. Observation wells installed for this study by the U.S. Geological Survey in the Valle de Yabucoa, Puerto Rico

5. Lithologic description of alluvium samples obtained at the Central Roig drill site, Valle de Yabucoa, Puerto Rico.

6. Lithologic description of alluvium samples obtained at the Calabazas drill site, Valle de Yabucoa, Puerto Rico.

7. Lithologic description of alluvium samples obtained at the Playita drill site, Valle de Yabucoa, Puerto Rico.

8. Lithologic description of alluvium samples obtained at the Martorell drill site, Valle de Yabucoa, Puerto Rico.

9. Lithologic description of alluvium samples obtained at the Limones drill site, Valle de Yabucoa, Puerto Rico.

10. Lithologic description of alluvium samples obtained at the Juan Martín drill site, Valle de Yabucoa, Puerto Rico

11. Lithologic description of alluvium samples obtained at the Sun drill site, Valle de Yabucoa, Puerto Rico

12. Lithologic description of alluvium samples obtained at the Harbor drill site, Valle de Yabucoa, Puerto Rico.

13. Lithologic description of alluvium samples and specific conductance of ground water obtained during drilling at the saline observation well drill site, Valle de Yabucoa, Puerto Rico

14. Ground-water altitude and water specific conductance at the deep observation well in the Valle de Yabucoa, Puerto Rico.

15. Ground-water altitude in 1991 and 1995 at 5 wells in the lower Valle de Yabucoa, Puerto Rico.

16. Stream discharge data at selected sites in the Valle de Yabucoa, Puerto Rico on July 5,1990

17. Selected physical and chemical properties of water samples from the Valle de Yabucoa alluvial aquifer, Puerto Rico.

18. Values for $\mathrm{Eh}, \mathrm{pH}$, and iron and manganese concentrations for water samples collected from the Valle de Yabucoa, Puerto Rico and plotted in figure 8

19. Geometric mean concentrations of iron and manganese in water produced from high-production industrial and municipal water-supply wells (high) and abandoned and low production private wells (low) in the Valle de Yabucoa, Puerto Rico 
CONVERSION FACTORS AND ABBREVIATED UNITS

\begin{tabular}{rlll}
\hline Multiply & By & To obtain \\
\hline kilometer $(\mathrm{km})$ & 0.62137 & mile \\
meter $(\mathrm{m})$ & 3.2808 & feet \\
centimeter $(\mathrm{cm})$ & 0.3937 & inch \\
millimeter $(\mathrm{mm})$ & 0.03937 & inch \\
micrometer $(\mu \mathrm{m})$ & 0.00003937 & inch \\
square kilometer $\left(\mathrm{km}^{2}\right)$ & 0.3861 & square mile \\
cubic meters per second $\left(\mathrm{m}^{3} / \mathrm{s}\right)$ & 35.31467 & cubic feet per second \\
cubic meters per second $\left(\mathrm{m}^{3} / \mathrm{s}\right)$ & 15,850 & gallons per minute \\
Liters per second $(\mathrm{L} / \mathrm{s})$ & 15.85032 & gallons per minute \\
cubic meters per day per meter of drawdown & 0.05992 & gallons per minute per foot of drawdown \\
\hline
\end{tabular}

Temperature: In this report temperatures are given in degrees Celsius $\left({ }^{\circ} \mathrm{C}\right)$.

Temperatures may be converted to degrees Fahrenheit $\left({ }^{\circ} \mathrm{F}\right)$ as follows:

$$
F=\left(9 / 5 x^{\circ} \mathrm{C}\right)+32
$$

Abbreviated water-quality, concentration, and geophysical units used in this report: micrograms per liter $(\mu \mathrm{g} / \mathrm{L})$

micrograms per gram $(\mu \mathrm{g} / \mathrm{g})$

milligram per liter $(\mathrm{mg} / \mathrm{L})$

microsiemens per centimeter at $25^{\circ} \mathrm{C}(\mu \mathrm{S} / \mathrm{cm})$

millisiemens per meter $(\mathrm{mS} / \mathrm{m})$

Microsiemens per centimeter can be converted to millisiemens per meter as follows: $10 \mu \mathrm{S} / \mathrm{cm}=1 \mathrm{mS} / \mathrm{m}$

Ohm-meters can be converted to millisiemens per meter as follows:

$\Omega-\mathrm{m}=1,000 /(\mathrm{mS} / \mathrm{m})$ 


\title{
Geochemical Properties and Saline-Water Intrusion in the Valle de Yabucoa Alluvial Aquifer, Southeastern Puerto Rico
}

\author{
By Joseph W. Troester and Ronald T. Richards
}

\section{ABSTRACT}

The Valle de Yabucoa alluvial aquifer is located along the southeastern coast of Puerto Rico and is the municipal and industrial water supply for the town of Yabucoa. The aquifer consists of more than 100 meters of alluvium overlying relatively impermeable bedrock. Water in the aquifer has iron and manganese concentrations as high as 28 and 3.6 milligrams per liter, respectively. Although the elevated iron and manganese concentrations in the aquifer pose no health threat, they frequently exceed the secondary standards for drinking water established by the U.S. Environmental Protection Agency of 0.3 milligrams per liter for iron and 0.05 milligrams per liter for manganese. Pumping from the aquifer for industrial use and public supply has lowered the water table to below sea level in some areas and has reversed the natural gradient of the water table toward the ocean. The saline-freshwater interface appears to have migrated landward because of this gradient reversal. A subsequent reduction in the rate of pumping has caused the water table to rise and may have stopped the landward migration of saline water. Two surface electromagnetic geophysical techniques (the terrain conductivity method and the transient electromagnetic method) were used to map depth to bedrock and the position of the saline-freshwater interface. Pumping and the shape of the bedrock-alluvium contact appear to control the extent and location of the saline-freshwater interface. The data indicate that saline-water intrusion probably is confined to the lowest part of the aquifer in a narrow paleochannel incised in the bedrock.

\section{INTRODUCTION}

The principal economic activities within the Valle de Yabucoa in southeastern Puerto Rico are related to agriculture (sugarcane, pasture, and plantains) and manufacturing (by an oil refinery, a cigarette manufacturing plant, and a sugar mill). The alluvial aquifer, which underlies the $45-\mathrm{km}^{2}$ valley floor, supplies nearly all of the water used for domestic, commercial, and industrial purposes. Locally, ground-water quality can be considered unsuitable for some uses because of the presence of high concentrations of dissolved iron and manganese. Elevated concentrations of these elements probably do not pose a human health threat, but both have a low taste threshold, contribute to water hardness, and readily stain kitchen and bathroom fixtures and laundry (Viessman and Hammer, 1985). The U.S. Environmental Protection Agency secondary standards for drinking water are $0.3 \mathrm{mg} / \mathrm{L}$ for iron and $0.05 \mathrm{mg} / \mathrm{L}$ for manganese (U.S. House of Representatives, 1996). In 1989, the U.S. Geological Survey (USGS), in cooperation with the Puerto Rico Aqueduct and Sewer Authority (PRASA) began an investigation to determine the sources of iron and manganese and the mechanisms controlling their distribution in the ground water in the Valle de Yabucoa alluvial aquifer. 
In July 1990, water levels were measured in wells throughout the valley and a water-level cone of depression was detected near the coast (Collar and others, 1990). At that time, withdrawal of ground water for industrial use and for public supply had lowered water levels in the center of this cone of depression to $12 \mathrm{~m}$ below mean sea level and caused the potentiometric surface to slope from the ocean to the pumping center, $2 \mathrm{~km}$ from the coast.

Because some wells had already been adversely affected by the saline intrusion, the U.S Geological Survey entered into additional cooperative agreements with the Puerto Rico Industrial Development Company (PRIDCO) in 1992 and PRASA in 1994 to address this threat of saline-water intrusion to the public and industrial water supply. The on-going investigation of elevated iron and manganese concentrations in the ground water was expanded to locate and define the saline-freshwater interface and the controls, including the depth to bedrock, on saline intrusion in the Valle de Yabucoa alluvial aquifer.

\section{Purpose and Scope}

This report summarizes the results of a study to describe the hydrogeology and geochemistry of the Valle de Yabucoa alluvial aquifer and to define the occurrence and potential for saline-water intrusion in the aquifer, which includes mapping the depth to bedrock in the lower part of the valley. The study was conducted in the Valle de Yabucoa in southeastern Puerto Rico (fig. 1). The scope of the investigation included the collection and evaluation of waterquality, ground-water, and surface-water data. Waterquality samples were collected from 44 wells. In July of 1990, stream-discharge and water-level data were collected from a number of streams and wells throughout the valley to define the extent of the cone of depression in the water table potentiometric surface.

A surface geophysical survey of the valley using two electromagnetic techniques (the terrain conductivity method and the transient electromagnetic method) was undertaken to define the depth to bedrock and the location of the saline-freshwater interface.
Collection of geophysical field data began in December of 1990 and continued until June 1991. Several observation wells were drilled throughout the valley to determine water quality and the change in hydraulic head in the aquifer with depth. The data from the geophysical surveys were used to determine the best location for the deepest and last observation well. That observation well was constructed between November 1992 and February 1993 and water-level and water specific conductance data were collected from February 1993 until November 1995. This well will continue to be useful for monitoring the intrusion of saline water into the Valle de Yabucoa.

\section{Acknowledgments}

The authors gratefully acknowledge the individuals who provided assistance to this project. We would especially like to thank Sucesores Roig, Inc. and the Puerto Rico Land Authority for allowing access to their land and permitting the installation of observation wells on their property. We would also like to thank Puerto Rico Sun Oil, Inc. and the Central Roig for their assistance. The authors are deeply indebted to the workers from the Central Roig and the plantain groves who on numerous occasions helped extricate our vehicles from the clay-rich surficial deposits.

\section{GEOLOGY, CLIMATE, AND GEOMORPHOLOGY OF THE VALLE DE YABUCOA}

The Valle de Yabucoa is a $45 \mathrm{~km}^{2}$ alluvial valley along the southeastern coast of Puerto Rico (fig. 1). The valley is surrounded by the hills of the San Lorenzo Batholith on three sides and by the Caribbean Sea on the fourth. The study area has a tropical marine climate and receives an average annual precipitation of about $2,046 \mathrm{~mm}$. The intense precipitation is drained by the Río Guayanés, Caño de Santiago, the Río del Ingenio, and minor tributaries. 


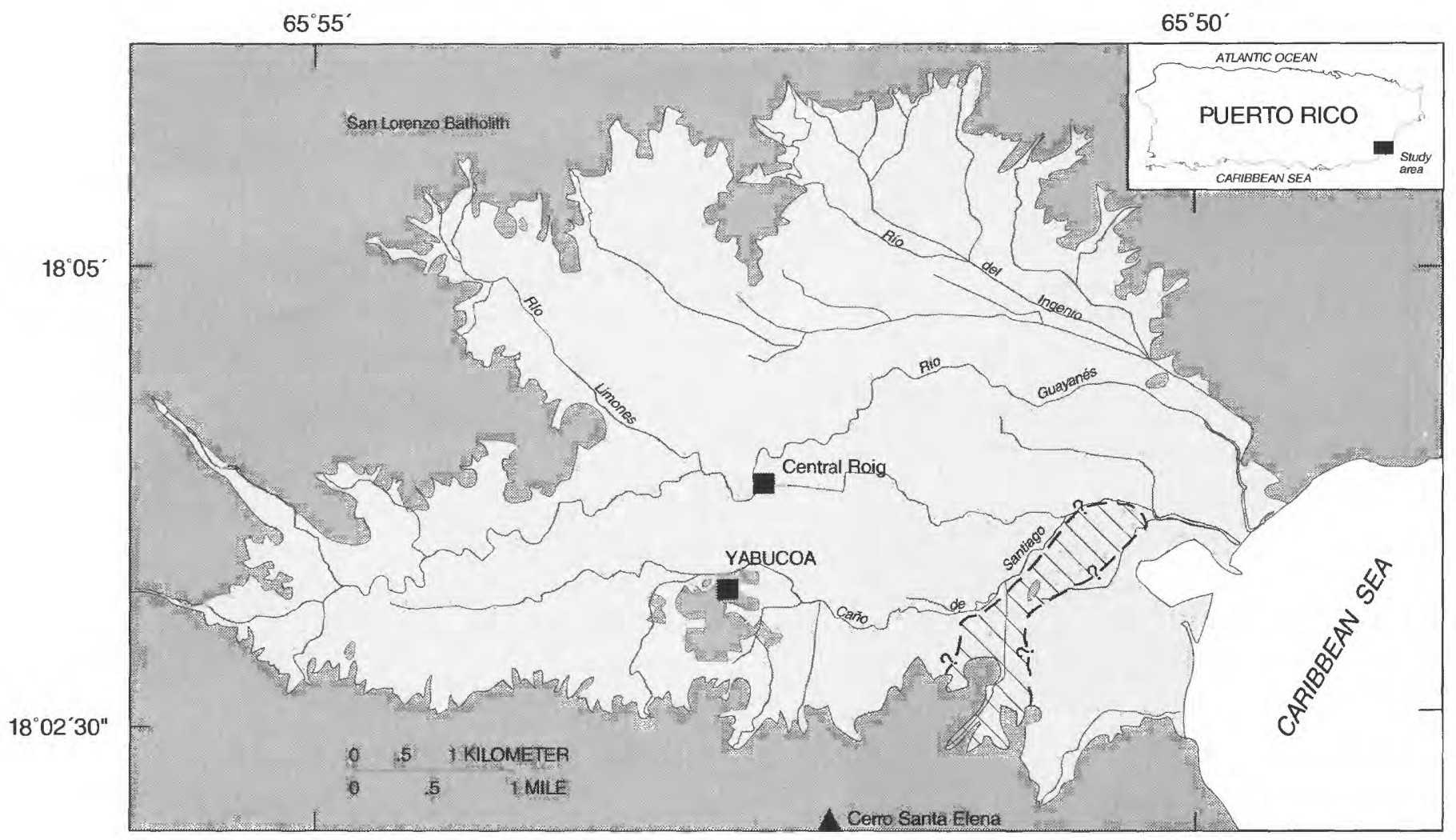

EXPLANATION

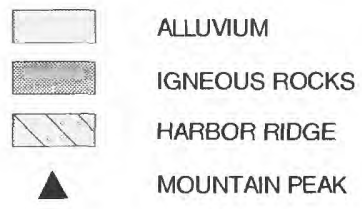

Figure 1. Location of the Valle de Yabucoa, Puerto Rico, the boundary of the alluvial valley fill, major streams, and cultural features.

\section{Geology}

The early work on the geology of southeastern Puerto Rico was conducted by Lobeck (1922), Fettke (1924a, b), and Meyerhoff (1933). More recently, general geologic maps of Puerto Rico have been produced by Briggs and Akers (1965) and Cox and Briggs (1973). Detailed geologic maps of the study area were produced by Rogers (1977) and Rogers and others (1979).

\section{San Lorenzo Batholith}

The hills surrounding the Valle de Yabucoa are composed of the San Lorenzo Batholith, a large, igneous intrusive body. These plutonic rocks were first described by Fettke (1924a). According to Rogers (1977), the San Lorenzo Batholith is a composite body that occupies an area of about $500 \mathrm{~km}^{2}$ in southeastern Puerto Rico and is composed of gabbro, diorite, tonalite, granodiorite, and quartz monzonite. Rogers and others (1979) divided the batholith into three major units, which from oldest to youngest include a diorite and gabbro unit, the granodiorite of San Lorenzo (and associated tonalite facies), and the plutonic complex of Punta Guayanés. The batholith also contains a few roof pendants of metavolcanic rock. Potassium-argon ages of the rocks (Cox and others, 1977; Rogers, 1977) indicate that the rocks were emplaced over a period of at least 12 million years during the Late Cretaceous and possibly the Early Paleocene. 
The oldest unit, which is composed of diorite and gabbro, is exposed in the southwestern part of the Punta Guayanés quadrangle, south of the Valle de Yabucoa. This unit is intruded by both the San Lorenzo and Punta Guayanés rock units. According to Rogers (1977) the average composition of the rock, based on 17 modal analyses, is about 58 percent plagioclase, 3.5 percent quartz, 32 percent hornblende, 2.5 percent augite, 3.5 percent magnetite, 0.5 percent sphene, and minor orthoclase, apatite, and zircon. The plagioclase is andesine, ranges locally to sodic labradorite, and is generally partially altered to sericite and clay minerals.

The granodiorite and associated tonalite of the San Lorenzo unit were named by Rogers (1977) after the town of San Lorenzo, which is to the northwest of the Valle de Yabucoa. The granodiorite is part of a pluton that comprises at least 75 percent of the San Lorenzo Batholith. The rocks are exposed in a part of the northern Punta Guayanés quadrangle and in most of the Yabucoa quadrangle. The tonalite facies is exposed in the southwestern part of the Punta Guayanés quadrangle. Based on the outcrop pattern, Rogers (1977) suggests that the tonalite underlies most of the alluvium in the Valle de Yabucoa. The rocks of granodiorite and tonalite of the San Lorenzo unit are intruded by the plutonic complex of the Punta Guayanés unit. According to Rogers (1977) the average composition of the granodiorite, based on 16 modal analyses, is about 49 percent plagioclase, 12 percent orthoclase (20 percent of the total feldspar), 17 percent quartz, 17 percent hornblende, 2.5 percent biotite, 1.5 percent magnetite, 0.5 percent sphene, and minor augite, apatite, and zircon (percentages do not add to 100 because of rounding). The plagioclase is largely andesine but locally ranges from andesine to calcic oligoclase. The average composition of the tonalite, based on 17 modal analyses, is about 56 percent plagioclase, 4 percent orthoclase ( 7 percent of total feldspar), 23 percent quartz, 10 percent hornblende, 4 percent biotite, 1 percent magnetite, and minor augite, sphene, apatite, and zircon (percentages do not add to 100 because of rounding).

Mineralogically, the tonalite closely resembles the granodiorite of San Lorenzo.
The youngest major unit within the San Lorenzo Batholith consists of many smaller plutons that range from quartz monzonite and granodiorite near the center of the batholith to tonalite near the margin. Rogers (1977) informally named the complex after Punta Guayanés. The rocks are exposed in the northern part of the Punta Guayanés quadrangle, to the north of the Valle de Yabucoa. According to Rogers (1977) the average composition of the main pluton of the Punta Guayanés complex, based on 20 modal analyses, is about 51 percent plagioclase, 13 percent orthoclase ( 20 percent of total feldspar), 32 percent quartz, 4 percent mafic minerals (biotite and very subordinate hornblende), 0.5 percent magnetite, and minor accessory sphene, apatite, and zircon (percentages do not add to 100 because of rounding). Plagioclase is largely oligoclase but ranges to sodic andesine.

The San Lorenzo Batholith in the study area contains no known mines or prospects. According to Rogers (1977) and Rogers and others (1979), rare traces of copper mineralization occur in all the major plutonic units and generally include chalcopyrite, malachite, and azurite. Rogers (1977) reports that a semi-quantitative spectrographic analysis of a mineralized nodule showed 2 percent copper, 0.3 percent manganese, more than 10 percent iron, and 0.3 percent titanium. Rogers and others (1979) report a small but rich mineralized zone found about $1.2 \mathrm{~km}$ west-northwest of Maunabo, just south of the study area. A semi-quantitative spectrographic analysis of a composite sample measured a content of more than 10 percent of both copper and iron, 0.2 percent titanium, $700 \mathrm{mg} / \mathrm{kg}$ vanadium, and $300 \mathrm{mg} / \mathrm{kg}$ manganese.

To the north of the study area, in the Humacao quadrangle, appreciable quantities of magnetite have been observed in a diorite-hornblendite complex that is part of the San Lorenzo Batholith (Cox and Briggs, 1973; M'Gonigle, 1978). Colony and Meyerhoff (1935) and Cadilla (1963) discuss this titaniferous iron ore prospect and the abandoned exploratory tunnels in detail. Colony and Meyerhoff (1935) report four partial chemical analyses of the ore with $\mathrm{Fe}_{2} \mathrm{O}_{3}$ concentrations ranging from 12.66 to 78.83 percent and $\mathrm{TiO}_{2}$ concentrations ranging from 0.93 to 5.35 percent. 


\section{Alluvium}

More than $100 \mathrm{~m}$ of alluvium overlie the San Lorenzo Batholith in the Valle de Yabucoa. The alluvium was derived from the erosion of the batholith. Mineral grains and rock fragments were transported and then deposited by the streams in the valley. The alluvium is composed of sand, silt, and clay with occasional pebbles, cobbles, and boulders and minor amounts of calcareous shell fragments and organic material. Most of the sand is yellowish-brown to medium-gray in color and intimately mixed with the yellowish-brown to grayish-green silt and clay. The sand is coarser and the sand beds are thicker and more common with increasing distance inland from the coast. However, there are large local variations in aggregate sand thickness and character. Beach and swamp deposits are present close to the coast. The mineralogy and chemistry of the alluvium and beach deposits have been studied by Guillou and Glass (1957), Collar and others (1990), Troester and others (1990a, b), and Marsh (1992a, b).

Alluvium samples were obtained from cores collected during drilling. Thin sections were prepared from grain mounts and analyzed petrographically with both optical and electron microscopy coupled with energy-dispersive spectroscopy. These methods determined that the alluvium is composed of plagioclase (andesine), quartz, orthoclase, a calciumand iron-rich amphibole, biotite, magnetite, and ilmenite grains. Microscopy also identified iron oxide coating on grains and, probably, maghemite, $\gamma-\mathrm{Fe}_{2} \mathrm{O}_{3}$, an alteration of magnetite. Small, 2- to 5-mm crystals of chalcopyrite were also found. X-ray diffraction of the clay-size fraction indicates that the major clay minerals are kaolinite, mica, and smectite, with minor amounts of vermiculite, goethite and hematite. Microscopy indicates that manganous ilmenite comprises about 0.2 percent of the aquifer alluvium. The ilmenite $\left(\mathrm{Fe}_{1.0-0.8}, \mathrm{Mn}_{0.0-0.2}\right) \mathrm{TiO}_{3}$ contains from about 0 to 20 percent manganese substituting for iron in a solid solution with pyrophanite, $\mathrm{MnTiO}_{3}$. The ilmenite is being altered to leucoxene (a combination of rutile, $\mathrm{TiO}_{2}$; anatase, $\mathrm{TiO}_{2}$; and sphene,
$\left.\mathrm{CaTiO}\left(\mathrm{SiO}_{4}\right)\right)$. Additional results of the solid-phase part of this study were reported by Troester and others (1990a, b).

Guillou and Glass (1957) studied the beach sands of Puerto Rico. In the heavy mineral fraction of their samples from the beach along the Valle de Yabucoa they found magnetite, pyroxene (augite), epidote, sphene, garnet, clinozoisite, zircon, and chlorite (listed in approximate relative abundance from most abundant to least).

Marsh (1992a, b) collected and semiquantitatively analyzed stream sediment samples from Puerto Rico. Of the 2,852 chemical analyses reported, 22 were for sites within the Yabucoa or Punta Guayanés quadrangles. Table 1 lists the minimum, maximum, and average chemical concentration of selected x 10 elements for these 22 samples.

The soils developed on the alluvium belong to the Coloso-Toa-Bajura association. These are deep, moderately well drained to poorly drained, nearly level soils on flood plains. The soils range in composition from clay to silty clay to silty clay loam (Boccheciamp, 1977).

\section{Climate}

The average annual temperature of Puerto Rico is about $25^{\circ} \mathrm{C}$. Nearly constant easterly trade winds occur across the island. Precipitation is measured daily at about 70 weather stations, and temperature and pan evaporation are measured at about 20 and 8 stations, respectively. Precipitation patterns in Puerto Rico are a result of the orographic effect of the central mountains on the easterly trade winds. Tropical storms and hurricanes occasionally strike the island, but more often they pass at some distance. The anomalously high wind and rain generated by the passage of these storms through the vicinity of Puerto Rico can affect the island for several days. The average annual precipitation varies across the island and ranges from more than $4,000 \mathrm{~mm}$ in a rain forest in the northeast, to less than $900 \mathrm{~mm}$ along most of the southern coast. 
Table 1. Minimum, maximum, and average chemical concentrations for the 22 stream sediment samples in the Yabucoa and Punta Guayanés quadrangles from Marsh (1992a, b)

$[<$, less than; $\mu \mathrm{g} / \mathrm{g}$, micrograms per gram $]$

\begin{tabular}{|c|c|c|c|c|c|c|}
\hline Element & \multicolumn{2}{|c|}{ Minimum } & \multicolumn{2}{|c|}{ Maximum } & \multicolumn{2}{|c|}{ Average } \\
\hline Calcium (Ca) & 1 & weight percent & 5 & weight percent & 2.3 & weight percent \\
\hline Iron $(\mathrm{Fe})$ & 1.5 & weight percent & 10 & weight percent & 6.5 & weight percent \\
\hline Magnesium (Mg) & 0.2 & weight percent & 1.5 & weight percent & 1.0 & weight percent \\
\hline Sodium (Na) & 1 & weight percent & 5 & weight percent & 1.9 & weight percent \\
\hline Phosphorus (P) & $<0.2$ & weight percent & $<0.2$ & weight percent & $<0.2$ & weight percent \\
\hline Titanium (Ti) & 0.3 & weight percent & 1 & weight percent & 0.5 & weight percent \\
\hline Silver (Ag) & $<0.5$ & $\mu \mathrm{g} / \mathrm{g}$ & $<0.5$ & $\mu \mathrm{g} / \mathrm{g}$ & $<0.5$ & $\mu \mathrm{g} / \mathrm{g}$ \\
\hline Arsenic (As) & $<200$ & $\mu \mathrm{g} / \mathrm{g}$ & $<200$ & $\mu \mathrm{g} / \mathrm{g}$ & $<200$ & $\mu \mathrm{g} / \mathrm{g}$ \\
\hline Boron (B) & $<10$ & $\mu \mathrm{g} / \mathrm{g}$ & $<10$ & $\mu \mathrm{g} / \mathrm{g}$ & $<10$ & $\mu \mathrm{g} / \mathrm{g}$ \\
\hline Barium (Ba) & 200 & $\mu \mathrm{g} / \mathrm{g}$ & 1,500 & $\mu \mathrm{g} / \mathrm{g}$ & 780 & $\mu \mathrm{g} / \mathrm{g}$ \\
\hline Beryllium (Be) & $<1$ & $\mu \mathrm{g} / \mathrm{g}$ & 1 & $\mu \mathrm{g} / \mathrm{g}$ & $<1$ & $\mu \mathrm{g} / \mathrm{g}$ \\
\hline Bismuth (Bi) & $<10$ & $\mu \mathrm{g} / \mathrm{g}$ & $<10$ & $\mu \mathrm{g} / \mathrm{g}$ & $<10$ & $\mu \mathrm{g} / \mathrm{g}$ \\
\hline Cadmium (Cd) & $<20$ & $\mu \mathrm{g} / \mathrm{g}$ & $<20$ & $\mu \mathrm{g} / \mathrm{g}$ & $<20$ & $\mu \mathrm{g} / \mathrm{g}$ \\
\hline Cobalt (Co) & $<10$ & $\mu \mathrm{g} / \mathrm{g}$ & 50 & $\mu \mathrm{g} / \mathrm{g}$ & 23 & $\mu \mathrm{g} / \mathrm{g}$ \\
\hline Chromium (Cr) & 10 & $\mu \mathrm{g} / \mathrm{g}$ & 200 & $\mu \mathrm{g} / \mathrm{g}$ & 50 & $\mu \mathrm{g} / \mathrm{g}$ \\
\hline Copper $(\mathrm{Cu})$ & 15 & $\mu \mathrm{g} / \mathrm{g}$ & 50 & $\mu \mathrm{g} / \mathrm{g}$ & 34 & $\mu \mathrm{g} / \mathrm{g}$ \\
\hline Gallium (Ga) & 50 & $\mu \mathrm{g} / \mathrm{g}$ & 70 & $\mu \mathrm{g} / \mathrm{g}$ & 54 & $\mu \mathrm{g} / \mathrm{g}$ \\
\hline Germanium (Ge) & $<10$ & $\mu \mathrm{g} / \mathrm{g}$ & $<10$ & $\mu \mathrm{g} / \mathrm{g}$ & $<10$ & $\mu \mathrm{g} / \mathrm{g}$ \\
\hline Lanthanum (La) & $<50$ & $\mu \mathrm{g} / \mathrm{g}$ & 50 & $\mu \mathrm{g} / \mathrm{g}$ & $<50$ & $\mu \mathrm{g} / \mathrm{g}$ \\
\hline Manganese (Mn) & 300 & $\mu \mathrm{g} / \mathrm{g}$ & 1,500 & $\mu \mathrm{g} / \mathrm{g}$ & 1,130 & $\mu \mathrm{g} / \mathrm{g}$ \\
\hline Molybdenum (Mo) & $<5$ & $\mu \mathrm{g} / \mathrm{g}$ & $<5$ & $\mu \mathrm{g} / \mathrm{g}$ & $<5$ & $\mu \mathrm{g} / \mathrm{g}$ \\
\hline Niobium (Nb) & $<20$ & $\mu \mathrm{g} / \mathrm{g}$ & $<20$ & $\mu \mathrm{g} / \mathrm{g}$ & $<20$ & $\mu \mathrm{g} / \mathrm{g}$ \\
\hline Nickel (Ni) & $<5$ & $\mu \mathrm{g} / \mathrm{g}$ & 30 & $\mu \mathrm{g} / \mathrm{g}$ & 10 & $\mu \mathrm{g} / \mathrm{g}$ \\
\hline Lead $(\mathrm{Pb})$ & 10 & $\mu \mathrm{g} / \mathrm{g}$ & 100 & $\mu \mathrm{g} / \mathrm{g}$ & 27 & $\mu \mathrm{g} / \mathrm{g}$ \\
\hline Antimony (Sb) & $<100$ & $\mu \mathrm{g} / \mathrm{g}$ & $<100$ & $\mu \mathrm{g} / \mathrm{g}$ & $<100$ & $\mu \mathrm{g} / \mathrm{g}$ \\
\hline Scandium (Sc) & 5 & $\mu \mathrm{g} / \mathrm{g}$ & 30 & $\mu \mathrm{g} / \mathrm{g}$ & 22 & $\mu \mathrm{g} / \mathrm{g}$ \\
\hline $\operatorname{Tin}(\mathrm{Sn})$ & $<10$ & $\mu \mathrm{g} / \mathrm{g}$ & 20 & $\mu \mathrm{g} / \mathrm{g}$ & $<10$ & $\mu \mathrm{g} / \mathrm{g}$ \\
\hline Strontium (Sr) & 200 & $\mu \mathrm{g} / \mathrm{g}$ & 500 & $\mu \mathrm{g} / \mathrm{g}$ & 310 & $\mu \mathrm{g} / \mathrm{g}$ \\
\hline Thorium (Th) & $<100$ & $\mu \mathrm{g} / \mathrm{g}$ & $<100$ & $\mu \mathrm{g} / \mathrm{g}$ & $<100$ & $\mu \mathrm{g} / \mathrm{g}$ \\
\hline Vanadium (V) & 50 & $\mu \mathrm{g} / \mathrm{g}$ & 1,500 & $\mu \mathrm{g} / \mathrm{g}$ & 490 & $\mu \mathrm{g} / \mathrm{g}$ \\
\hline Wolfram (W) & $<20$ & $\mu \mathrm{g} / \mathrm{g}$ & $<20$ & $\mu \mathrm{g} / \mathrm{g}$ & $<20$ & $\mu \mathrm{g} / \mathrm{g}$ \\
\hline Yttrium (Y) & $<10$ & $\mu \mathrm{g} / \mathrm{g}$ & 70 & $\mu \mathrm{g} / \mathrm{g}$ & 37 & $\mu \mathrm{g} / \mathrm{g}$ \\
\hline Zinc (Zn) & $<200$ & $\mu \mathrm{g} / \mathrm{g}$ & 200 & $\mu \mathrm{g} / \mathrm{g}$ & $<200$ & $\mu \mathrm{g} / \mathrm{g}$ \\
\hline Zirconium (Zr) & 150 & $\mu \mathrm{g} / \mathrm{g}$ & $>1,000$ & $\mu \mathrm{g} / \mathrm{g}$ & 480 & $\mu \mathrm{g} / \mathrm{g}$ \\
\hline Gold (Au) & $<0.00$ & $\mu \mathrm{g} / \mathrm{g}$ & 0.3 & $\mu \mathrm{g} / \mathrm{g}$ & 0.01 & $\mu \mathrm{g} / \mathrm{g}$ \\
\hline
\end{tabular}


The National Oceanic and Atmospheric Administration maintains one meteorological station in the study area at the Central Roig in about the center of the Valle de Yabucoa. The station is operated daily by the Puerto Rico Sugar Corporation and is officially named Yabucoa 1 NNE, Puerto Rico (669829). The yearly annual precipitation, average annual temperature, and annual pan evaporation for this station for some recent years with nearly complete data are listed in table 2 . The average annual precipitation was reported by Calvesbert (1970) as 2,242 $\mathrm{mm}$. More recently the Southeast Regional Climate Center reported the normal precipitation for the years 1961 to 1990 as 2,046 $\mathrm{mm}$ (Southeast Regional Climate Center, unpublished data, 1995). Precipitation generally increases in the higher altitudes to the west and decreases toward the ocean in the east.

Precipitation occurs throughout the year in Puerto Rico, but there is a relative dry season, usually lasting from January or February to March or April. Rainfall is usually heaviest in May, August, September, and October. The monthly normal precipitation values (1961-90) for the metrological station at the Central Roig are shown in figure 2. The
Southeast Regional Climate Center has calculated the normal annual average temperature at this metrological station for the years $1961-90$ as $25.7{ }^{\circ} \mathrm{C}$. The difference between the average temperature for the coldest months $\left(23.9^{\circ} \mathrm{C}\right.$ in January and February) and the hottest month $\left(27.2^{\circ} \mathrm{C}\right.$ in August) is less than $4{ }^{\circ} \mathrm{C}$.

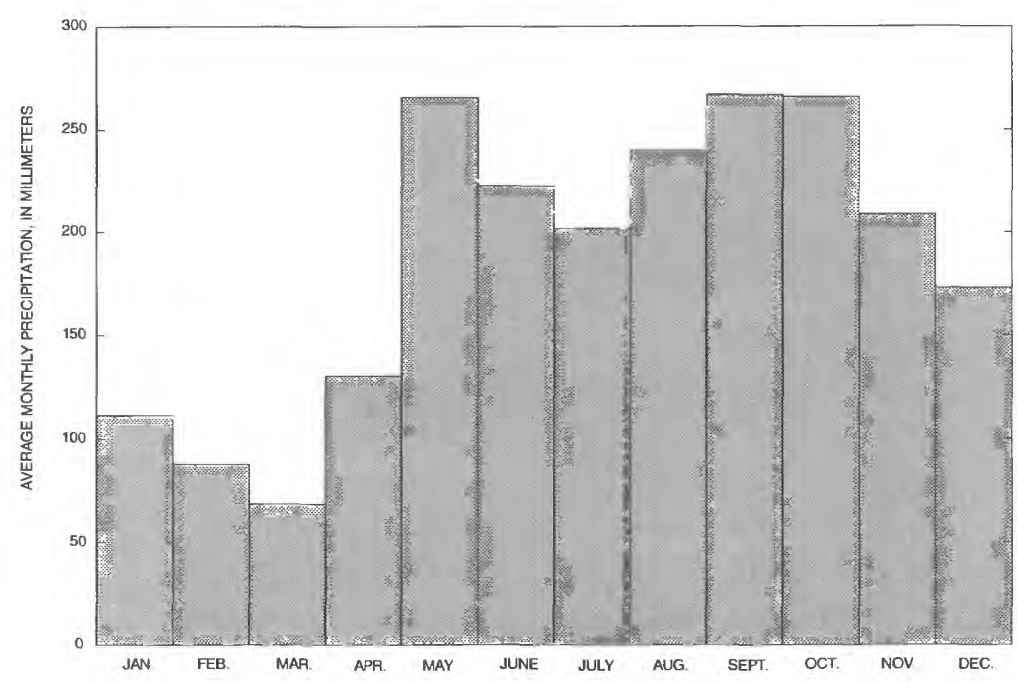

Figure 2. Precipitation histogram of the average monthly precipitation at the Central Roig, Yabucoa, Puerto Rico (from Calvesbert, 1970).

Table 2. Annual precipitation, average temperature, and annual pan evaporation for the National Oceanic and Atmospheric Administration weather station at Central Roig, in Yabucoa, Puerto Rico [na, not available]

\begin{tabular}{lccc}
\hline Year & $\begin{array}{c}\text { Annual } \\
\text { precipitation, } \\
\text { in millimeters }\end{array}$ & $\begin{array}{c}\text { Average } \\
\text { temperature, in } \\
\text { degrees Celsius }\end{array}$ & $\begin{array}{c}\text { Annual pan } \\
\text { evaporation, in } \\
\text { millimeters }\end{array}$ \\
\hline 1987 & 2,722 & 26.5 & 1,719 \\
1988 & 2,056 & na & 1,805 \\
1989 & 1,684 & 25.4 & 1,786 \\
1990 & 1,452 & 25.7 & 1,765 \\
1991 & 1,599 & 26.0 & 1,733 \\
Average for 1987-91 & 1,903 & 25.9 & 1,762 \\
Annual averages from Calvesbert (1970) & 2,242 & na & na \\
Climatological normals for 1961-90 & 2,046 & 25.7 & na \\
(Southeast Regional Climate Center, & & & \\
unpublished data, 1995) & & & \\
\hline
\end{tabular}


Little evaporation or evapotranspiration data exist for Puerto Rico. According to Calvesbert (1970), the potential evaporation at coastal stations exceeds the precipitation, while at interior stations the precipitation exceeds the potential evaporation. The average annual pan evaporation reported at the Central Roig for the years 1987-91 is $1,762 \mathrm{~mm}$, which is about 93 percent of the average annual precipitation of $1,903 \mathrm{~mm}$ for the same 5-year period (table 2). However, pan evaporation is a measure of potential evaporation. Actual evapotranspiration is frequently less than the measured pan evaporation.

Giusti and López (1967) estimated annual evapotranspiration for a river basin west of Yabucoa, the Río Grande de Patillas Basin. In that basin, they derived a value for evapotranspiration from the drainage area $\left(65 \mathrm{~km}^{2}\right)$, the average precipitation $(1,905 \mathrm{~mm})$, and the average discharge $\left(3.94 \mathrm{~m}^{3} / \mathrm{s}\right)$ at the Río Grande de Patillas at Patillas, USGS Station 50094200. The value they determined for evapotranspiration was about $760 \mathrm{~mm}$ or about 40 percent of the precipitation. The value for evapotranspiration in the Valle de Yabucoa may be similar to this amount, which is less than the reported annual pan evaporation. The 40 percent value is in agreement with previous studies of the hydrology of the area (Anders, 1971; Robison and Anders, 1973). which assumed that evapotranspiration was about 50 percent of precipitation.

\section{Geomorphology (Landforms and Drainage)}

The altitude of the hills surrounding the Valle de Yabucoa reaches a maximum of about $650 \mathrm{~m}$ at the head of the Río Guayanés basin. The land surface in the Valle de Yabucoa slopes gently from an altitude of about $30 \mathrm{~m}$ above mean sea level at western edge of the valley to sea level where the valley meets the Caribbean Sea. The hills flanking the valley and the material underlying the alluvium within the valley consist of the San Lorenzo Batholith and related rocks.

The Río Guayanés, with a drainage area of 88 $\mathrm{km}^{2}$, is the largest stream flowing through the Valle de Yabucoa. The study area is also drained by the Caño de Santiago, the Río del Ingenio, the Río Limones, and several smaller streams. Large floods, such as the one that occurred on September 6, 1960, with the near passage of Hurricane Donna, flooded almost the entire Valle de Yabucoa (Fields, 1971). Floods of this magnitude are infrequent.

During the Pleistocene, sea level was as much as $120 \mathrm{~m}$ lower than it is today (Fairbanks, 1989). At that time the Río Guayanés cut a deep valley into the underlying bedrock as the stream eroded down toward base level. The paleovalley of the Río Guayanés and its principal tributaries was not only much deeper than the present valley, but the valley surface was much more irregular. Ridges now partly or completely buried extended far out into the valley, and isolated or semi-isolated hills rose rather abruptly from the valley floor. The location of one of these ridges, Harbor Ridge, is shown in figure 1.

As sea level began to rise to its current position, the valley was gradually filled by alluvial material, possibly behind a bay-mouth bar. In addition to alluvium there are swamp and beach deposits in the eastern part of the valley fill. Harbor Ridge probably existed as a peninsula, or as a peninsula and a small island, in the partly submerged valley. The island and at least the northern part of the ridge were completely covered by the sea when it rose higher. Presumably, the sea also occupied that part of the valley west and northwest of Yabucoa. Most of the alluvial material that filled the valley was derived from the surrounding hills. Harbor Ridge near the mouth of the valley probably acted as a barrier to the inland movement of sediments transported by sea currents.

As a result of shifts in the positions of the ancestral streams, periodic advances and retreats of the sea, and the presence of hills and ridges, the deposited thickness of alluvium and its grain-size distribution varies appreciably over short distances. Harbor Ridge is a major subsurface feature in the underlying bedrock topography that strongly influenced the geology and hydrology of this part of the valley and affected the amount of sand deposited in the overlying alluvium. According to Anders (1971), the southern half of the ridge is close to the surface, and the thickness of the overlying alluvium there is less than 3 $\mathrm{m}$. From about its midpoint, the ridge declines to the northeast. Near the Caño de Santiago, the crest of the 
ridge is about $15 \mathrm{~m}$ below sea level and only about $9 \mathrm{~m}$ above the adjacent ancestral valley floor. Along the northern half of the ridge, the effect of the ridge on the total thickness of alluvium is much less pronounced. The maximum thickness of the alluvium in the Valle de Yabucoa is not known, but it probably exceeds the $107 \mathrm{~m}$ penetrated by the deep observation well that was drilled as part of this study (Richards and Troester, 1991, 1993). The bottom of the alluvium is probably at or slightly above the minimum altitude of sea level during the Pleistocene, which was near 120 $\mathrm{m}$ below the current mean sea level (Fairbanks, 1989).

The contact between the top of the weathered San Lorenzo Batholith and the base of the alluvium forms an irregular erosional surface. According to Anders (1971), topographic relief on this ancient surface is known to exceed $12 \mathrm{~m}$ in a horizontal distance of less than $150 \mathrm{~m}$ at some places, but even greater relief may occur elsewhere. Excluding the effect of the buried ridges and taking the alluviated valley as a whole, these topographic irregularities may not be exceptionally important hydrologically. The partly or nearly completely buried ridges extending far out into the valley, however, may alter the subsurface hydrology significantly because the ridges form a partial barrier to the normal seaward movement of ground water. In addition, the Harbor Ridge, which is near the sea, appears to have appreciably delayed the inland movement of saline water as pumping lowered ground-water levels inland from the ridge.

\section{METHODS}

\section{Drilling Methods}

The USGS used an air-rotary drilling rig with a hollow stem auger to install wells up to $60 \mathrm{~m}$ deep at eight locations in the Valle de Yabucoa. Most of the observation wells were constructed with 5-cm PVC casing, although three--Central Roig 1, Calabazas, and Playita 1--were constructed with 10-cm PVC casing. During drilling, samples of the aquifer material were collected by using a split spoon sampler in the middle of the hollow stem auger. Samples were usually collected from the surface down until the movement of ground water carried fine sand into the hollow stem and caused the split spoon sampler to bind. Because of this problem, samples were seldom collected from more than $15 \mathrm{~m}$ below land surface.

A private contractor used a dual-tube, reverse air-rotary drilling system with an open-center bit to drill one well. With this drilling method, a large compressor forces air down the annulus between the dual-walls of the drill stem. The compressed air forces the drill cuttings, cores, and ground water into the open center of the bit where they are carried to the surface up the center of the drill stem. This method allows the specific conductance of the ground water to be measured without the interfering effects of drilling mud. The contractor constructed the observation well with 5-cm PVC casing.

\section{Electromagnetic Surface Geophysics Methods}

Two electromagnetic surface geophysical methods were used to determine the depth to bedrock, the approximate depth of the saline-freshwater interface, and aquifer characteristics. The terrain conductivity (TC) method was used as a reconnaissance tool because this method permits rapid data collection. Subsequently, the transient electromagnetic (TEM) method was used. Of the two methods, TEM method provides better vertical resolution and can penetrate to a greater depth.

\section{Terrain Conductivity (TC) Method}

The TC method is a dual loop profiling tool that can directly measure the apparent electrical conductivity of the ground. The depth to which this equipment can measure apparent electrical conductivity is limited to about $60 \mathrm{~m}$ (McNeill, 1991). The EM34-3, produced by Geonics, was used for this method. This equipment operates at frequencies of $400,1,600$, and $6,400 \mathrm{~Hz}$ and at coil separations of 10 , 20 , and $40 \mathrm{~m}$. The wider coil separations use lower frequencies to probe to greater depths. In addition, the equipment can be used in either the vertical or horizontal dipole modes for each of the 10-, 20-, and $40-\mathrm{m}$ coil separations. These coil orientating and coil separations provided six values of apparent 
conductivity for each of 84 sites in the Valle de Yabucoa. A more detailed discussion of this equipment and techniques used can be found in McNeill (1980, 1983).

The six measurements of apparent conductivity obtained for each of the sites were analyzed using the EMIX34 computer program by Interpex. This program assumes a layered earth model and uses a set of userdefined values of layer conductivities and depths as a starting model for each site. A synthetic curve is computed by the program from the starting model. Once the field data are plotted as conductivities and thicknesses versus depth, the program tries to find the best fit between the field data and a synthetic curve. The result is a one-dimensional geoelectric model at each data-collection site.

\section{Transient Electromagnetic (TEM) Method}

The TEM method measures the time-decay curve of an induced electromagnetic field. The decay curve can be transformed into a one-dimensional geoelectric model of the changes in conductivity with depth using interpretation software (McNeill, 1991). This method can measure apparent electrical conductivity to a much greater depth than the TC method and, depending on the size of the transmitter loop, can operate to depths of up to a few kilometers. The equipment used in this part of the project, was the EM47 produced by Geonics with a square transmitter loop of 40 or $100 \mathrm{~m}$ on a side. The depth of penetration can be as much as twice the diameter of the transmitter loop. The use of two repetition frequencies in this study permitted the collection of 40 values of apparent conductivity for each of the 31 sites in the Valle de Yabucoa. The $40 \mathrm{~m}$ loop was used at 27 of these sites, and the 100-m loop was used in the remaining four sites. A more complete description of the physics of the TEM method can be found in Fitterman and Stewart (1986).

The data obtained for each of the sites were analyzed using the TEMIX47 computer program by Interpex. Similar to the EMIX34 program, this program also assumes a layered earth model, and uses a set of user-defined values of layer conductivities and depths as a starting model for each site. A synthetic curve is computed by the program from the starting model. Once the field data are plotted as conductivities and thicknesses versus depth, the program tries to find the best fit between the field data and a synthetic curve.

\section{Geochemical Methods}

Water samples were collected from existing production and abandoned wells and from the new wells drilled as part of this investigation. Abandoned and new wells were sampled with submersible pumps following the evacuation of at least three well volumes of water. Production wells were sampled using the available pump.

Field measurements of water temperature and specific conductance were collected with a YSI Model 33 meter. Field measurements of $\mathrm{pH}$ and alkalinity were conducted with an Orion $\mathrm{pH}$ meter using procedures described by Wood (1976). Field Eh measurements were also collected with the Orion $\mathrm{pH}$ meter and an Eh probe, corrected using ZoBell solution, and following the procedures described by Wood (1976).

Water samples were collected, filtered through a $0.45 \mu \mathrm{m}$ filter, acidified with nitric acid, refrigerated, and analyzed in the laboratory for calcium, magnesium, sodium, potassium, silica, iron, and manganese. Water samples were collected, filtered through a $0.45 \mu \mathrm{m}$ filter, refrigerated, and analyzed for chloride, sulfate, and fluoride. Water samples were collected, filtered through a $0.45 \mathrm{~mm}$ filter, preserved with mercuric chloride, refrigerated, and analyzed for phosphate, nitrite, and nitrite plus nitrate. Water samples were collected, filtered through a $0.10 \mu \mathrm{m}$ filter, acidified with nitric acid, refrigerated, and analyzed for aluminum. Water samples were collected, filtered through a $0.45 \mu \mathrm{m}$ filter in a stainless steel filter unit, refrigerated, and analyzed for dissolved organic carbon. Water samples were collected, preserved with zinc acetate, refrigerated, and analyzed for hydrogen sulfide. All laboratory analyses were preformed by the U.S. Geological Survey National Water Quality Laboratory using methods described in detail by Fishman and Friedman (1989). Additionally, a Hach spectrophotometer and reagents were used in the field to measure iron, manganese, and dissolved oxygen colorimetrically. 
Alluvium samples were obtained from cores collected during drilling. Thin sections were prepared from grain mounts and analyzed petrographically with both optical and electron microscopy coupled with energy-dispersive spectroscopy. The techniques of the solid-phase study were reported by Troester and others (1990a, b).

\section{HYDROGEOLOGY OF THE VALLE DE YABUCOA ALLUVIAL AQUIFER}

The Valle de Yabucoa alluvial aquifer is composed of yellowish-brown to medium-gray sand, silt, and clay with occasional pebbles, cobbles, and boulders eroded from the San Lorenzo Batholith and deposited in the paleovalley of the Río Guayanés. The aquifer has a maximum thickness of more than $100 \mathrm{~m}$, but is probably less than $120 \mathrm{~m}$.

The hydrogeology of the Valle de Yabucoa alluvial aquifer has been previously described by Anders (1971) and Robison and Anders (1973). These studies were conducted when the main economic activity in the valley was the growing and processing of sugar cane and prior to the construction of the major industries now operating in the valley. Anders (1971) gives a detailed description of factors that influence the hydrogeology of the area. Robison and Anders (1973) report on the results of an analog model that was constructed to simulate the effects of long-term pumping.

The shape of the bedrock surface below the alluvium appears to partly control ground-water flow. Anders (1971, p. 16) discusses the Harbor Ridge and its effect on ground-water flow and states that this ridge "may appreciably delay the inland movement of saline-water if pumping lowers ground-water levels inland from the ridge." He went on to predict that any serious saline-water encroachment was likely to occur north of the Caño de Santiago, where the Harbor Ridge was not present (Anders, 1971, p. 46).

A pre-development potentiometric-surface map of the area modified from Anders (1971, p. 32) is shown in figure 3 . The water table is usually less than $10 \mathrm{~m}$ below land surface, except where the water table has been lowered by pumping. The direction of ground-water flow is generally to the east.

Much of the ground-water recharge to the valley probably occurs by the direct infiltration of precipitation. Ground water is also recharged along the small alluvial fans which flank the valley. Some recharge occurs from streambed infiltration (Anders, 1971), though some stream reaches gain water rather than lose. Recharge probably also occurs directly from fractures in the bedrock surrounding and underlying the alluvial aquifer. Prior to ground-water development in the valley, most ground-water discharged directly to the ocean.

Anders (1971) reports seven values of specific capacity and transmissivity from aquifer tests at different wells completed in the alluvial aquifer. Transmissivity at these sites ranged from 20 to 340 $\mathrm{m}^{2} / \mathrm{d}$, and averaged about $130 \mathrm{~m}^{2} / \mathrm{d}$. Specific capacity ranged from 90 to $520\left(\mathrm{~m}^{3} / \mathrm{d}\right) / \mathrm{m}$ of drawdown, and averaged about $290\left(\mathrm{~m}^{3} / \mathrm{d}\right) / \mathrm{m}$ of drawdown.

Robison and Anders (1973) constructed an electrical analog model of the aquifer to simulate the effects of long-term pumping. Based on their model, at a ground-water pumping rate of about $6 \mathrm{~m}^{3} / \mathrm{s}$ saline water would not reach theoretical production wells along the Zanja Barra for about 200 years.

Unfortunately, the model did not consider the migration of highly mineralized water occurring nearer the production wells.

The wells in the Valle de Yabucoa alluvial aquifer that are discussed in this report are listed in tables 3 and 4 . The location of each of these wells is shown on the map in figure 4.

Nineteen wells were drilled and installed as part of this investigation. Eighteen of the wells were drilled by the USGS and one well was drilled by a private contractor. Drilling and construction data for the 19 wells are listed in table 4. Lithologic descriptions of the alluvium samples obtained at each of the eight drill sites are listed in tables 5 to 12 . The locations of these wells are shown in figure 4. 


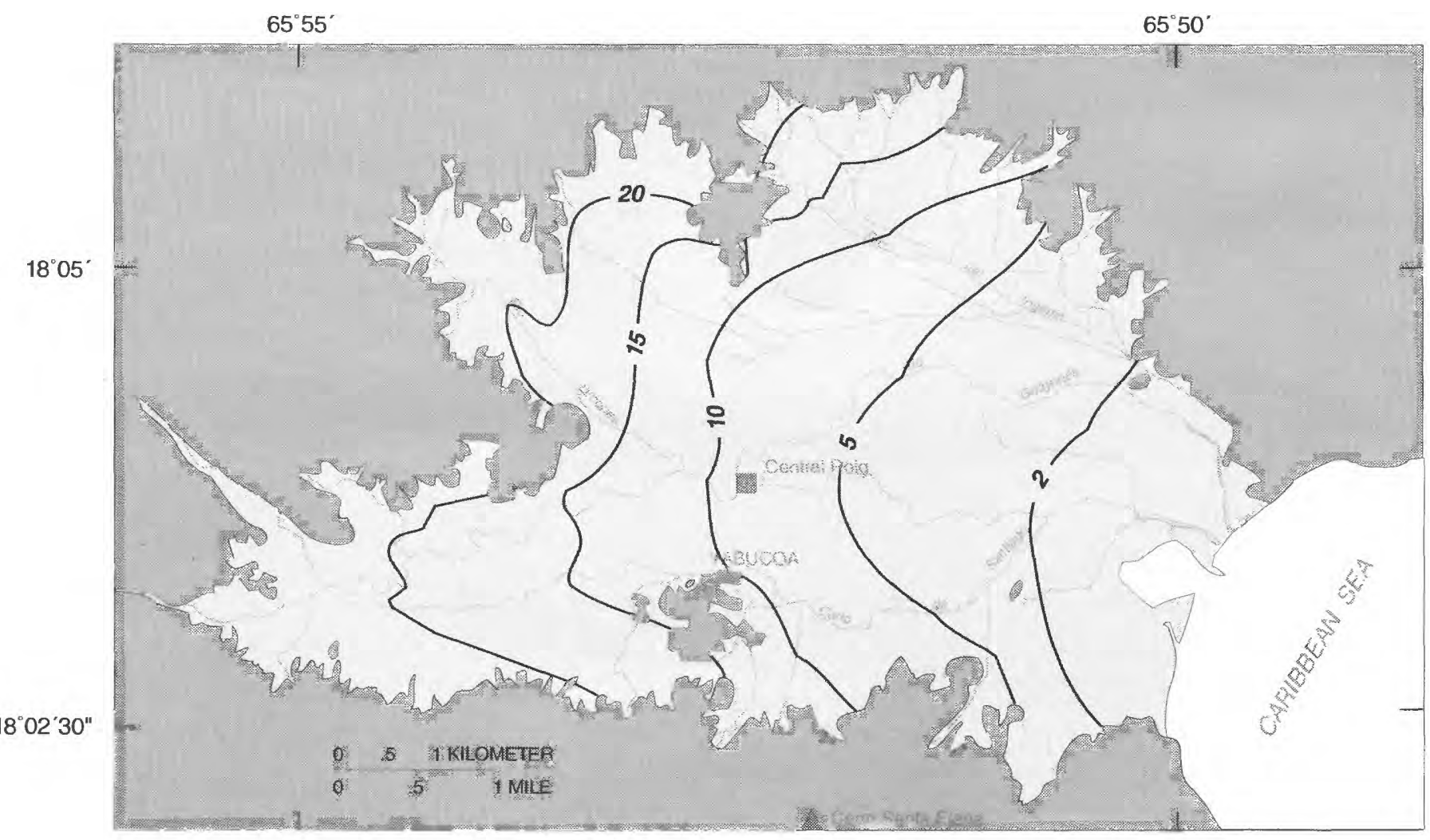

EXPLANATION

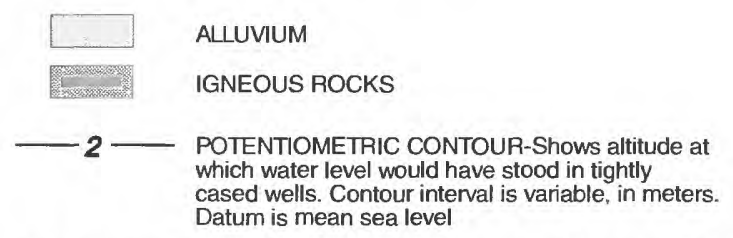

Figure 3. Pre-development potentiometric-surface map of the Valle de Yabucoa, Puerto Rico (modified from Anders, 1971, p. 32).

Table 3. Description of selected wells completed in the Valle de Yabucoa alluvial aquifer, Puerto Rico [na, not available; PRASA, Puerto Rico Aqueduct and Sewer Authority]

\begin{tabular}{ccrrl}
\hline $\begin{array}{c}\text { Well } \\
\text { number }\end{array}$ & Local well names & USGS Site ID & Other identifier & \multicolumn{1}{c}{ Use } \\
\hline 1 & Sun Oil \#01 Well & 180331065510600 & 03-65.50-06-08 & $\begin{array}{l}\text { Industrial water supply with large submersible } \\
\text { pump }\end{array}$ \\
2 & Sun Oil \#02 Well & 180336065511200 & $03-65.51-03-48$ & $\begin{array}{l}\text { Industrial water supply with large submersible } \\
\text { pump } \\
\text { Industrial water supply with large submersible } \\
\text { pump }\end{array}$ \\
4 & Sun Oil \#03 Well & 180333065512900 & $03-65.51-02-46$ & $\begin{array}{l}\text { Not used at time of sampling. Subsequently used } \\
\text { for industrial water supply } \\
\text { Industrial water supply with large submersible } \\
\text { pump }\end{array}$ \\
5 & Sun Oil \#06 Well & 180403065513200 & $04-65.51-06-95$ & $\begin{array}{l}\text { Not used at time of sampling. Previously used for } \\
\text { industrial water supply }\end{array}$
\end{tabular}


Table 3. Description of selected wells completed in the Valle de Yabucoa alluvial aquifer, Puerto Rico--Continued

\begin{tabular}{|c|c|c|c|c|}
\hline $\begin{array}{l}\text { Well } \\
\text { number }\end{array}$ & Local well names & USGS Site ID & Other identifier & Use \\
\hline 7 & $\begin{array}{l}\text { Union Carbide \#1 } \\
\text { Pozo Valle \#07 }\end{array}$ & 180456065515100 & $04-65.51-01-02$ & Industrial water supply with turbine pump \\
\hline 8 & $\begin{array}{l}\text { Union Carbide \#2 } \\
\text { Pozo Valle \#10 }\end{array}$ & 180442065515000 & $04-65.51-11-32$ & Industrial water supply with turbine pump \\
\hline 9 & $\begin{array}{l}\text { Union Carbide \#3 } \\
\text { Pozo Valle \#13 }\end{array}$ & 180459065514100 & $04-65.51-15-04$ & Not used at time of sampling \\
\hline 10 & $\begin{array}{l}\text { Union Carbide \#4 } \\
\text { Pozo Valle \#14 }\end{array}$ & 180459065514101 & $04-65.51-16-04$ & Industrial water supply with turbine pump \\
\hline 11 & Union Carbide \#5 & 180440065523200 & na & Industrial water supply with turbine pump \\
\hline 12 & $\begin{array}{l}\text { Union Carbide \#6 } \\
\text { Pozo Valle \#11 }\end{array}$ & 180456065514900 & $04-65.51-12-02$ & Industrial water supply with turbine pump \\
\hline 13 & Pozo Calabazas & 180330065550100 & $03-65.55-01-50$ & Public water supply with turbine pump \\
\hline 14 & $\begin{array}{l}\text { Central Roig } \\
\text { Pozo Yabucoa \#21 }\end{array}$ & 180351065525700 & $03-65.52-02-16$ & Industrial water supply with turbine pump \\
\hline 15 & $\begin{array}{l}\text { Pozo de la Grúa } \\
\text { (PRASA) }\end{array}$ & 180410065522900 & 04-65.52-09-85 & Public water supply with turbine pump \\
\hline 16 & $\begin{array}{l}\text { Limones (PRASA) } \\
\text { Pozo Central Roig }\end{array}$ & 180358065523700 & $03-65.52-08-05$ & Public water supply with turbine pump \\
\hline 17 & Viejo Roig (PRASA) & 180344065523000 & na & Public water supply with turbine pump \\
\hline 18 & $\begin{array}{l}\text { Guayanés (PRASA) } \\
\text { Pozo Yabucoa }\end{array}$ & 180416065501100 & $04-65.50-03-79$ & Public water supply with turbine pump \\
\hline 19 & $\begin{array}{l}\text { Test Well \#08 } \\
\text { Number } 1\end{array}$ & 180416065530100 & $04-65.53-02-80$ & Not used at time of sampling. \\
\hline 20 & Pozo Barrio Limones & 180505065542200 & $05-65.54-01-97$ & Not used at time of sampling. \\
\hline 21 & $\begin{array}{l}\text { R.J. Reynolds \#02 } \\
\text { Pozo Valle \# } 24\end{array}$ & 180522065511800 & $05-65.51-02-68$ & Industrial water supply with turbine pump \\
\hline 22 & $\begin{array}{l}\text { R.J. Reynolds \#03 } \\
\text { Pozo Valle \# } 25\end{array}$ & 180524065511500 & $05-65.51-03-68$ & Industrial water supply with turbine pump \\
\hline 23 & AH \#02 & 180548065513700 & $05-65.51-05-14$ & Not used at time of sampling. \\
\hline 24 & $\mathrm{AH} \# 03$ & 180334065523300 & $03-65.52-13-45$ & Not used at time of sampling. \\
\hline 25 & Pozo Martorell & 180405065544300 & $04-65.54-01-30$ & Not used at time of sampling. \\
\hline 26 & Manantial Rivera & 180204065550100 & $02-65.55-01-80$ & spring \\
\hline 27 & Manantial F. Rojas & 180224065550900 & $02-65.55-02-69$ & spring \\
\hline 28 & Manantial Rodríguez & 180202065520800 & $02-65.52-02-49$ & spring \\
\hline 48 & Pozo Yabucoa 7 & 180415065543900 & $04-65.51-05-74$ & $\begin{array}{l}\text { USGS observation well with automatic digital } \\
\text { recorder }\end{array}$ \\
\hline 49 & $\begin{array}{l}\text { Observation Well \#1 } \\
\text { TW-01 }\end{array}$ & 180349065502300 & $03-65.50-01-17$ & Abandoned \\
\hline 50 & $\begin{array}{l}\text { Observation Well \#2 } \\
\text { TW-01 }\end{array}$ & 180342065502300 & $03-65.50-04-27$ & Abandoned \\
\hline 51 & Pozo Valle \#1 & 180351065495700 & $03-65.49-02-11$ & Abandoned \\
\hline 52 & Pozo Valle \#6 & 180411065500900 & $04-65.50-02-89$ & Abandoned \\
\hline 53 & Port Authority Well & 180359065501301 & $03-65.50-07-08$ & Abandoned \\
\hline
\end{tabular}


Table 4. Observation wells installed for this study by the U.S. Geological Survey in the Valle de Yabucoa, Puerto Rico

\begin{tabular}{|c|c|c|c|c|}
\hline $\begin{array}{c}\text { Well } \\
\text { number }\end{array}$ & Well name & USGS Site ID & $\begin{array}{l}\text { Screened interval in feet } \\
\text { below land surface }\end{array}$ & $\begin{array}{l}\text { Total depth in feet } \\
\text { below land surface }\end{array}$ \\
\hline 29 & Central Roig I & 180358065523701 & 30 to 40 & 44 \\
\hline 30 & Central Roig 2 & 180358065523702 & 95 to 115 & 115 \\
\hline 31 & Calabazas & 180330065550100 & 41 to 61 & 61 \\
\hline 32 & Playita 1 & 180250065542200 & 88 to 108 & 108 \\
\hline 33 & Playita 2 & 180250065542201 & 40 to 50 & 50 \\
\hline 34 & Martorell 1 & 180451065532601 & 20 to 35 & 35 \\
\hline 35 & Martorell 2 & 180451065532602 & 55 to 75 & 75 \\
\hline 36 & Limones 1 & 180436065524801 & 101 to 121 & 121 \\
\hline 37 & Limones 2 & 180436065524802 & 15 to 35 & 35 \\
\hline 38 & Limones 3 & 180436065524803 & 57 to 77 & 77 \\
\hline 39 & Juan Martín 1 & 180425065520801 & 150 to 170 & 170 \\
\hline 40 & Juan Martín 2 & 180425065520802 & 109 to 129 & 129 \\
\hline 41 & Juan Martín 3 & 180425065520803 & 16 to 36 & 36 \\
\hline 42 & Sun 1 & 180414065513200 & 32 to 52 & 52 \\
\hline 43 & Sun 2 & 180414065513201 & 168 to 188 & 188 \\
\hline 44 & Harbor 1 & 180344065505001 & 79 to 99 & 99 \\
\hline 45 & Harbor 2 & 180344065505002 & 17 to 37 & 37 \\
\hline 46 & Harbor 3 & 180344065505003 & 125 to 145 & 145 \\
\hline 47 & Deep observation well & 180358065503600 & 330 to 340 & 350 \\
\hline
\end{tabular}

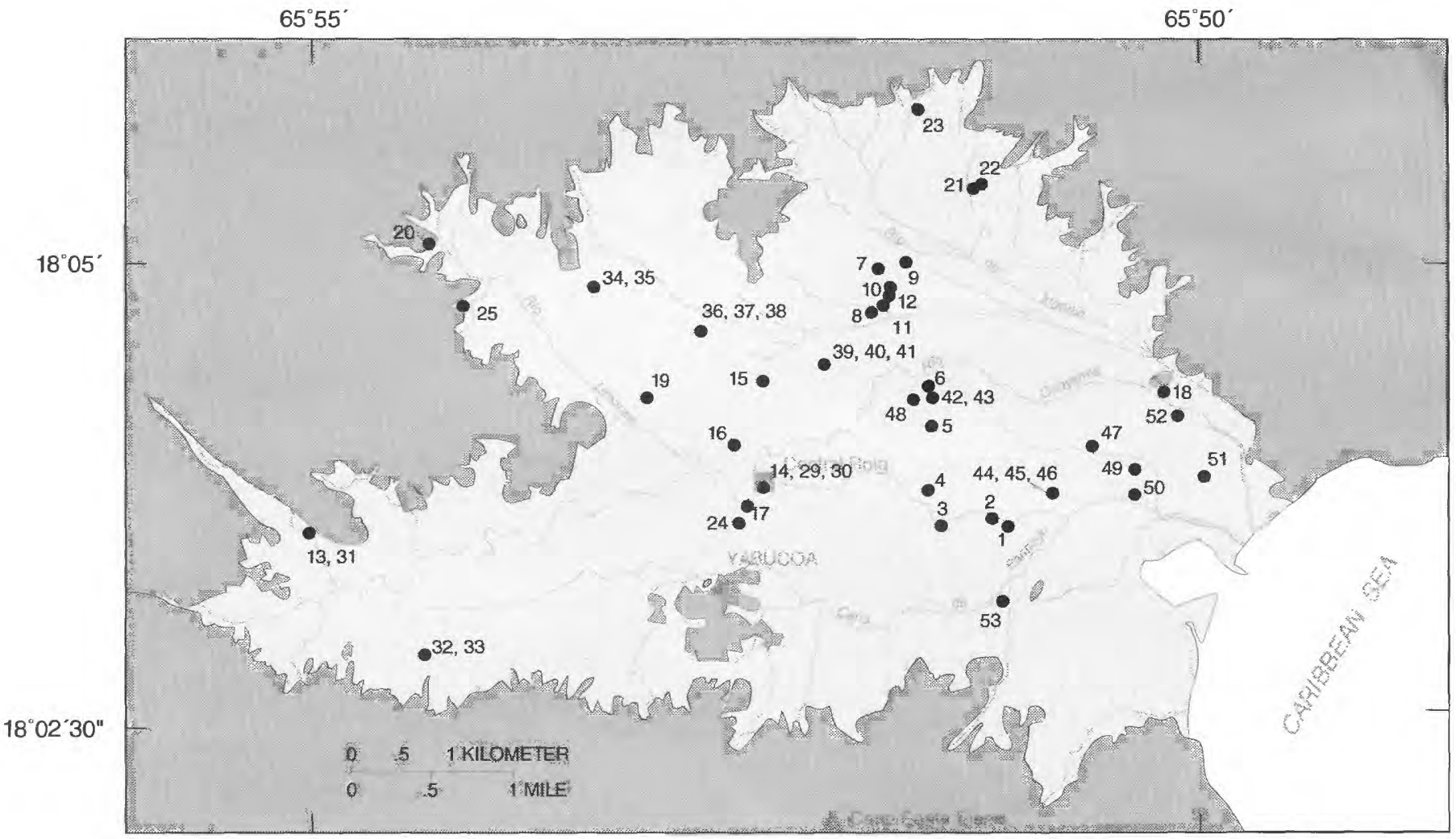

EXPLANATION

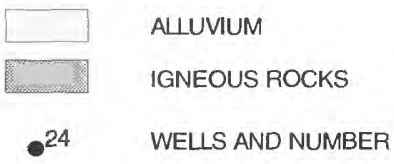

Figure 4. Locations of selected wells in the Valle de Yabucoa, Puerto Rico. 
Table 5. Lithologic description of alluvium samples obtained at the Central Roig drill site, Valle de Yabucoa, Puerto Rico

\begin{tabular}{cl}
\hline $\begin{array}{c}\text { Depth below land } \\
\text { surface, in feet }\end{array}$ & \multicolumn{1}{c}{ Lithologic Description } \\
\hline 0 to 4 & grayish-black clay \\
4 to 9 & grayish-olive-green clay \\
9 to 14 & light-olive-brown, medium sand \\
14 to 19 & grayish-black, medium to coarse sand \\
19 to 24 & moderate-olive-brown, fine sand \\
24 to 29 & moderate-olive-brown clay \\
29 to 34 & moderate-olive-brown, poorly sorted, \\
34 to 39 & medium to very coarse sand \\
39 to 44 & moderate-yellowish-brown, sandy clay \\
44 to 49 & moderate-brown, sandy clay \\
49 to 54 & moderate-brown, sandy clay \\
54 to 59 & moderate-yellowish-brown, medium sand \\
59 to 64 & light-brown, medium sand with some clay \\
64 to 69 & moderate-yellowish-brown, coarse sand \\
69 to 74 & moderate-yellowish-brown, fine sand \\
\hline
\end{tabular}

Table 7. Lithologic description of alluvium samples obtained at the Playita drill site, Valle de Yabucoa, Puerto Rico

\begin{tabular}{|c|c|}
\hline $\begin{array}{l}\text { Depth below land } \\
\text { surface, in feet }\end{array}$ & Lithologic Description \\
\hline 0 to 4 & dark-yellowish-brown, poorly sorted, coarse sand \\
\hline 4 to 9 & $\begin{array}{l}\text { moderate-yellowish-brown, poorly sorted, coarse } \\
\text { sand }\end{array}$ \\
\hline 9 to 14 & $\begin{array}{l}\text { moderate-yellowish-brown, poorly sorted, coarse } \\
\text { sand }\end{array}$ \\
\hline 14 to 19 & dark-yellowish-brown, poorly sorted, coarse sand \\
\hline 19 to 24 & light-brown, medium sand with silt and clay \\
\hline 24 to 29 & moderate-yellowish-brown, medium sand with clay \\
\hline 29 to 34 & moderate-yellowish-brown, medium to coarse sand \\
\hline 34 to 39 & pale-yellowish-brown, medium sand \\
\hline 39 to 44 & stiff clay with medium to coarse sand \\
\hline 44 to 49 & $\begin{array}{l}\text { moderate-brown, very poorly sorted, medium sand } \\
\text { with clay }\end{array}$ \\
\hline 49 to 54 & $\begin{array}{l}\text { moderate-brown, very poorly sorted, coarse sand } \\
\text { with clay }\end{array}$ \\
\hline 54 to 59 & no samples \\
\hline 59 to 64 & $\begin{array}{l}\text { moderate-yellowish-brown clay with medium to } \\
\text { fine sand }\end{array}$ \\
\hline
\end{tabular}

Table 6. Lithologic description of alluvium samples obtained at the Calabazas drill site, Valle de Yabucoa, Puerto Rico

\begin{tabular}{cl}
\hline $\begin{array}{c}\text { Depth below land } \\
\text { surface, in feet }\end{array}$ & \multicolumn{1}{c}{ Lithologic Description } \\
\hline 0 to 4 & clay with medium sand \\
4 to 9 & medium to fine sand with silt and clay \\
9 to 14 & poorly sorted, medium sand \\
14 to 19 & coarse sand with pebbles \\
19 to 24 & very coarse sand with some clay \\
24 to 29 & medium to coarse sand \\
29 to 34 & stiff clay \\
34 to 39 & stiff clay \\
39 to 44 & fine to very fine sand \\
44 to 49 & medium sand \\
49 to 54 & very stiff clay \\
54 to 59 & medium sand with interbedded clay \\
59 to 64 & coarse sand \\
\hline
\end{tabular}

Table 8. Lithologic description of alluvium samples obtained at the Martorell drill site, Valle de Yabucoa, Puerto Rico

\begin{tabular}{cl}
\hline $\begin{array}{c}\text { Depth below land } \\
\text { surface, in feet }\end{array}$ & \multicolumn{1}{c}{ Lithologic Description } \\
\hline 0 to 4 & $\begin{array}{l}\text { moderate yellowish brown poorly sorted } \\
\text { medium sand } \\
\text { moderate yellowish brown medium sand } \\
4 \text { to } 9\end{array}$ \\
9 to 14 & medium gray very fine sand, silt, and clay \\
14 to 19 & $\begin{array}{l}\text { light bluish gray poorly sorted coarse } \\
\text { sand }\end{array}$ \\
19 to 24 & no samples \\
24 to 29 & medium light gray coarse sand \\
29 to 34 & medium light gray coarse sand \\
34 to 39 & medium gray coarse sand \\
39 to 44 & brownish gray coarse sand \\
\hline
\end{tabular}


Table 9. Lithologic description of alluvium samples obtained at the Limones drill site, Valle de Yabucoa, Puerto Rico

\begin{tabular}{cl}
\hline $\begin{array}{c}\text { Depth below } \\
\text { land surface, } \\
\text { in feet }\end{array}$ & Lithologic Description \\
\hline 0 to 4 & grayish-orange, medium sand \\
4 to 9 & medium-dark-gray, medium to coarse sand \\
9 to 14 & medium-dark-gray, medium to coarse sand \\
14 to 19 & medium-gray, medium to coarse sand \\
\hline
\end{tabular}

Table 11. Lithologic description of alluvium samples obtained at the Sun drill site, Valle de Yabucoa, Puerto Rico

\begin{tabular}{cl}
\hline $\begin{array}{c}\text { Depth below } \\
\text { land surface, } \\
\text { in feet }\end{array}$ & \multicolumn{1}{c}{ Lithologic Description } \\
\hline 0 to 4 & $\begin{array}{l}\text { dark-yellowish-brown, very poorly sorted, coarse } \\
\text { sand }\end{array}$ \\
4 to 9 & $\begin{array}{l}\text { moderate-yellowish-brown, medium to fine sand } \\
\text { dark-gray, medium to coarse sand }\end{array}$ \\
9 to 14 & $\begin{array}{l}\text { dark-gray, medium to coarse sand } \\
14 \text { to } 19\end{array}$ \\
19 to 24 & $\begin{array}{l}\text { grayish-green clay with medium sand } \\
\text { grayish-green, medium sand }\end{array}$ \\
24 to 29 & dark-greenish-gray, medium sand with clay \\
34 to 39 & $\begin{array}{l}\text { medium-dark-gray, coarse sand } \\
\text { medium-gray, medium to coarse sand } \\
39 \text { to } 44\end{array}$ \\
44 to 49 & medium-dark-gray, medium to coarse sand \\
\hline
\end{tabular}

Table 10. Lithologic description of alluvium samples obtained at the Juan Martín drill site, Valle de Yabucoa, Puerto Rico

\begin{tabular}{cl}
\hline $\begin{array}{c}\text { Depth below } \\
\text { land surface, } \\
\text { in feet }\end{array}$ & \multicolumn{1}{c}{ Lithologic Description } \\
\hline 0 to 4 & $\begin{array}{l}\text { moderate-yellowish-brown, poorly sorted, } \\
\text { angular, medium sand }\end{array}$ \\
4 to 9 & $\begin{array}{l}\text { dark-yellowish-orange, poorly sorted, } \\
\text { medium to coarse sand }\end{array}$ \\
9 to 14 & $\begin{array}{l}\text { olive-gray, poorly sorted, medium sand to clay } \\
\text { olive-gray, poorly sorted, medium sand to clay } \\
14 \text { to } 19\end{array}$ \\
19 to 24 & medium-dark-gray, medium to coarse sand \\
\hline
\end{tabular}

Table 12. Lithologic description of alluvium samples obtained at the Harbor drill site, Valle de Yabucoa, Puerto Rico

\begin{tabular}{cl}
\hline $\begin{array}{c}\text { Depth below } \\
\text { land surface, } \\
\text { in feet }\end{array}$ & Lithologic Description \\
\hline 0 to 4 & dark-yellowish-brown, fine sand with clay \\
4 to 9 & greenish-black, medium to coarse sand \\
9 to 14 & dark-greenish-gray to black, stick, wet clay \\
14 to 19 & dark-greenish-gray, medium to coarse sand \\
19 to 24 & dark-greenish-gray, medium to coarse sand \\
\hline
\end{tabular}


In addition to the 18 wells drilled by the USGS, a 107-m-deep observation well was drilled by a private contractor into the deepest part of the paleochannel to monitor the movement of saline water into the aquifer on a long-term basis. The site for this well (fig. 4) was selected based on three criteria, the greatest depth to bedrock, likelihood of encountering saline water, and accessibility by the drill rig.

Construction details for this well are included in table 4 and lithologic description of alluvial samples and the specific conductance of ground water obtained during drilling are in table 13.

Table 13. Lithologic description of alluvium samples and specific conductance of ground water obtained during drilling at the saline observation well drill site, Valle de Yabucoa, Puerto Rico

[nd, not determined]

\begin{tabular}{|c|c|c|}
\hline $\begin{array}{l}\text { Depth below land } \\
\text { surface, in feet }\end{array}$ & $\begin{array}{c}\text { Specific } \\
\text { conductance, } \\
\text { in } \mu \mathrm{S} / \mathrm{cm}\end{array}$ & Lithologic Description \\
\hline 0 to 10 & nd & moderate-brown clay with some sand \\
\hline 10 to 20 & nd & moderate-brown sand with black clay \\
\hline 20 to 30 & 290 & black sand \\
\hline 30 to 40 & nd & black sand and clay \\
\hline 40 to 50 & nd & black sand and clay with $50 \mathrm{~mm}$ conch shell \\
\hline 50 to 60 & 600 & black sand and clay \\
\hline 60 to 70 & 590 & black to moderate-brown sand and clay \\
\hline 70 to 80 & 540 & moderate-brown sand \\
\hline 80 to 90 & 500 & moderate-brown coarse sand and clay \\
\hline 90 to 100 & 470 & no samples \\
\hline 100 to 110 & 520 & light-brown sand \\
\hline 110 to 120 & 540 & light-brown to dusky-brown sand with very-coarse quartz pebbles \\
\hline 120 to 130 & 490 & light-brown sand with very-coarse pebbles \\
\hline 130 to 140 & 480 & light-brown sand and pebbles \\
\hline 140 to 150 & 490 & light-brown sand and pebbles \\
\hline 150 to 160 & 500 & moderate-brown sand \\
\hline 160 to 170 & 490 & light-brown sand with light-brown to grayish-brown clay \\
\hline 170 to 180 & 510 & grayish-brown to light-brown sand and clay \\
\hline 180 to 190 & 540 & well sorted moderate-brown to grayish-brown sand with some pebbles \\
\hline 190 to 200 & 490 & well sorted moderate-brown sand \\
\hline 200 to 210 & 590 & poorly sorted moderate-brown sand with stiff, light-brown clay \\
\hline 210 to 220 & 580 & grayish-brown to moderate-brown sand with clay layers \\
\hline 220 to 230 & 610 & well sorted dusky-brown sand with quartz pebbles and coarse-pebble sized rock fragments \\
\hline 230 to 240 & 680 & well sorted moderate-brown sand with some pebbles \\
\hline 240 to 250 & 690 & moderate-brown sand and clay \\
\hline 250 to 260 & 830 & moderate-brown sand and clay \\
\hline 260 to 270 & 910 & well sorted moderate-brown sand \\
\hline 270 to 280 & 940 & moderate-brown to dusky-brown sand with some clay layers \\
\hline 280 to 290 & 990 & brownish-gray sand with some interbedded clay \\
\hline 290 to 300 & 1,040 & $\begin{array}{l}\text { hard moderate-reddish-brown clay and moderate-brown medium to coarse sand and clay with } \\
\text { pebble-sized rock fragments }\end{array}$ \\
\hline 300 to 310 & 970 & light-brown medium to coarse sand and pebbles with moderate-green clay layers \\
\hline 310 to 320 & 1,010 & light-brown medium to coarse sand with pebbles, some well cemented sands \\
\hline 320 to 330 & 990 & moderate-brown medium to fine sand with pebbles and with some interbedded clay \\
\hline 330 to 340 & 1,660 & $\begin{array}{l}\text { dusky-brown to moderate-brown to moderate-olive-brown medium sand with some clay layers, } \\
\text { well-cemented sand layers, and very coarse granodiorite pebbles }\end{array}$ \\
\hline 340 to 350 & 3,500 & moderate-olive-brown sand with pebbles and small cobbles and some clay layers \\
\hline
\end{tabular}


The deep observation well did not penetrate the consolidated granodiorite, but the well did penetrate the saprolite on top of the bedrock. This is the deepest well in the Valle de Yabucoa. The specific conductance of the water pumped to the land surface as the drill rig progressed through the alluvium revealed continuous freshwater with specific conductance values that fluctuated but remained below $700 \mu \mathrm{S} / \mathrm{cm}$ until about $75 \mathrm{~m}$ below land surface when the specific conductance began to rise to about 1,000 $\mu \mathrm{S} / \mathrm{cm}$. At about $100 \mathrm{~m}$ below land surface the specific conductance rose sharply to about $3,500 \mu \mathrm{S} / \mathrm{cm}$. The well is constructed with a $6.1-\mathrm{m}$ screen centered at 101 $\mathrm{m}$ below land surface. After casing, the water pumped from the well had a specific conductance that exceeded $10,000 \mu \mathrm{S} / \mathrm{cm}$ or about 20 percent of the specific conductance of sea water and more than ten times higher than the average specific conductance found elsewhere in the aquifer. The difference between the specific conductance values during drilling and after casing the well are due to the mixing of water of different specific conductance values during the drilling process. The land surface was estimated from topographic contours and a nearby highway survey to be about $0.8 \mathrm{~m}$ above mean sea level.

\section{WATER USE FROM THE VALLE DE YABUCOA ALLUVIAL AQUIFER}

\section{Water Use}

Ground-water withdrawals for industrial use from the Valle de Yabucoa alluvial aquifer increased with the construction of the refinery and the cigarette and graphite manufacturing plants in the 1970's. Ground-water withdrawal data for the refinery from 1978 through 1995 (fig. 5) are available from the Franchise Office of the Puerto Rico Department of Natural and Environmental Resources. No other consistent ground-water withdrawal data are available. Monthly average ground-water levels at the Yabucoa 7 observation well (number 48 in table 3 and fig. 4) and individual measurements of the ground-water level in the deep observation well installed for this project are also plotted in figure 5 .
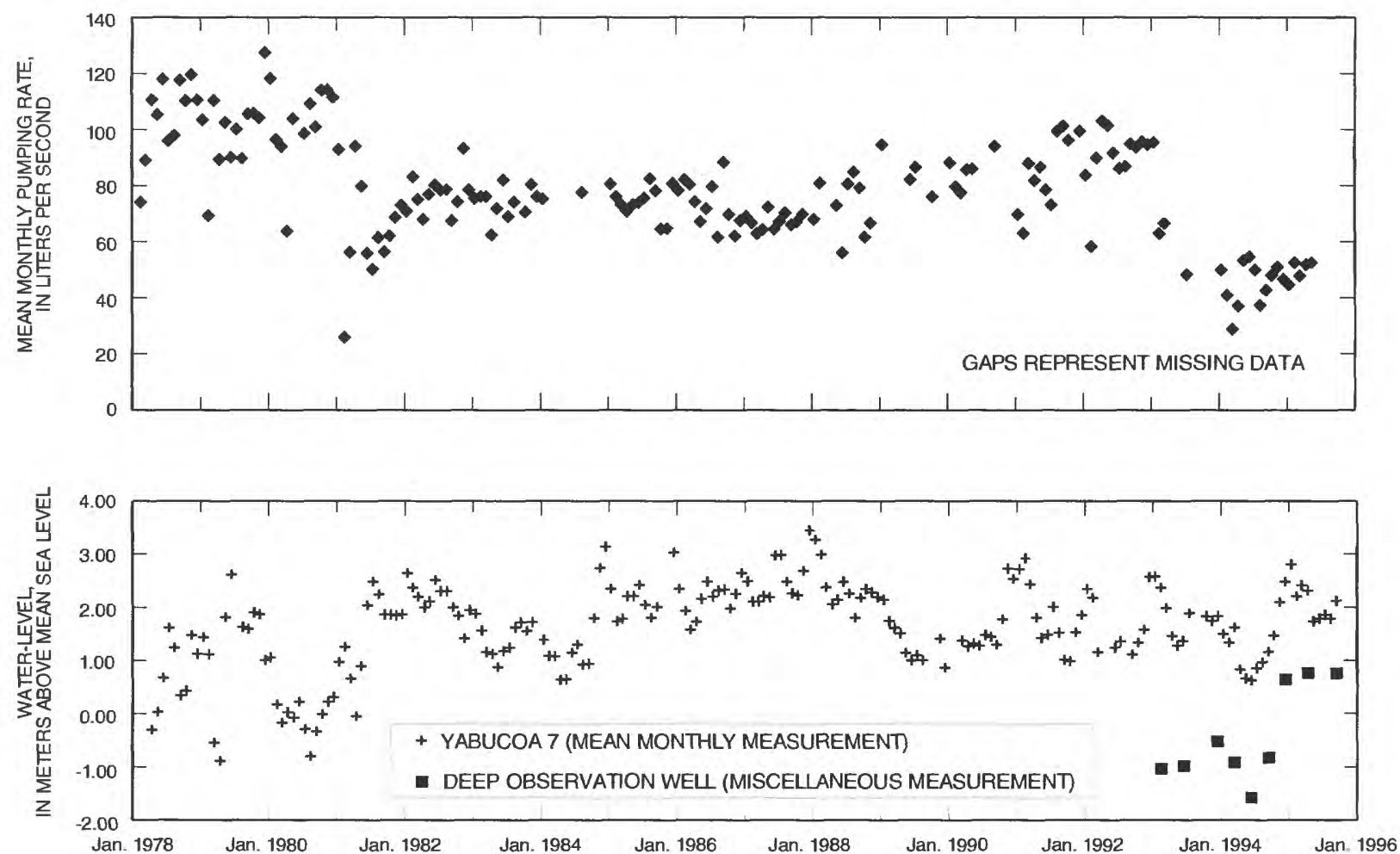

Figure 5. Pumping rate at the refinery and water levels in the Valle de Yabucoa alluvial aquifer in southeastern Puerto Rico. 
The water levels in the Yabucoa 7 observation well and the deep observation well appear to respond to changes in pumping reported by the refinery (fig. 5). These two wells are closer to the pumping center for the refinery than they are to any of the other pumping centers in the valley. During 1978 to 1980 , the refinery averaged more than $100 \mathrm{~L} / \mathrm{s}$ of ground-water withdrawals. During this period the monthly average ground-water level at the Yabucoa 7 observation well frequently dropped below mean sea level. At the end of 1980, the refinery reduced their average withdrawal rate to about $75 \mathrm{~L} / \mathrm{s}$. Since that time the average water level at the Yabucoa 7 observation well has not been below mean sea level. In 1993, the refinery again decreased their withdrawals to an average of less than $50 \mathrm{~L} / \mathrm{s}$. This decrease in pumping occurred during a widespread drought in Puerto Rico that extended from about August 1993 to about December 1994 (U.S. Geological Survey, 1994-96). Water levels did not appear to recover in the deep observation well until the beginning 1995. The water level in the deep observation well was below mean sea level every time the water level was measured from when the well was constructed in February 1993 until September 1994. During that time the water level averaged about $1.0 \mathrm{~m}$ below mean sea level. Since December 1994 the water levels have risen and they average about $0.7 \mathrm{~m}$ above mean sea level (December 1994 to September 1995). The individual measurements for the deep observation well are tabulated in table 14.

Water level rises similar to the one observed in the deep observation well were observed in five other wells in the lower part of the Valle de Yabucoa alluvial aquifer. Each of these wells recorded a rise of more than $1 \mathrm{~m}$ from between 1991 and 1995. The waterlevel data are listed in table 15.

\section{Potentiometric Surfaces}

On July 5, 1990, stream-discharge and waterlevel data were collected at 21 sites along streams and numerous wells throughout the valley to define the extent of the cone of depression in the water table. The estimated potentiometric surface of the aquifer (fig. 6) is modified from Collar and others (1990). The observed base of the cone of depression produced by the pumping wells is $12 \mathrm{~m}$ below mean sea level. In addition, the potentiometric surface appears to be below mean sea level everywhere between the pumping wells and the ocean.

Table 14. Ground-water altitude and water specific conductance at the deep observation well in the Valle de Yabucoa, Puerto Rico

[nd, not determined]

\begin{tabular}{lccc}
\hline \multicolumn{1}{c}{ Date } & $\begin{array}{c}\text { Ground-water altitude, in } \\
\text { meters below land surface } \\
\text { datum }\end{array}$ & $\begin{array}{c}\text { Ground-water altitude, in } \\
\text { meters above mean sea } \\
\text { level }\end{array}$ & $\begin{array}{c}\text { specific conductance, in } \\
\text { microsiemens per centimeter at } \\
2{ }^{\circ} \text { Celsius }\end{array}$ \\
\hline February 19, 1993 & 1.83 & -1.0 & 11,400 \\
June 29, 1993 & 1.77 & -1.0 & 10,700 \\
December 27, 1993 & 1.32 & -0.5 & 11,900 \\
March 17, 1994 & 1.71 & -0.9 & 12,000 \\
June 22, 1994 & 2.37 & -1.6 & 11,800 \\
September, 13, 1994 & 1.62 & -0.8 & 11,400 \\
December 30, 1994 & 0.16 & 0.6 & 11,500 \\
April 12, 1995 & 0.04 & 0.8 & 12,400 \\
September 13, 1995 & 0.04 & 0.8 & nd \\
\hline
\end{tabular}


Table 15. Ground-water altitude in 1991 and 1995 at 5 wells in the lower Valle de Yabucoa, Puerto Rico

\begin{tabular}{|c|c|c|c|c|c|c|}
\hline $\begin{array}{l}\text { Well } \\
\text { number }\end{array}$ & Local well name & $\begin{array}{l}\text { Date of } \\
\text { water-level } \\
\text { measurement } \\
\text { in } 1991\end{array}$ & $\begin{array}{l}\text { Water level in } \\
1991 \text {, in meters } \\
\text { below land } \\
\text { surface datum }\end{array}$ & $\begin{array}{c}\text { Date of } \\
\text { water-level } \\
\text { measurement } \\
\text { in } 1995\end{array}$ & $\begin{array}{l}\text { Water level in } \\
1995, \text { in meters } \\
\text { below land } \\
\text { surface datum }\end{array}$ & $\begin{array}{c}\text { Rise in water } \\
\text { level from } \\
1991 \text { to } 1995, \\
\text { in meters }\end{array}$ \\
\hline 49 & $\begin{array}{l}\text { Observation Well \#1 } \\
\text { TW-01 }\end{array}$ & January 3 & 1.30 & November 7 & 0.26 & 1.04 \\
\hline 50 & $\begin{array}{l}\text { Observation Well \#2 } \\
\text { TW-01 }\end{array}$ & January 3 & 1.20 & November 7 & 0.05 & 1.15 \\
\hline 51 & Pozo Valle \#1 & August 1 & 2.90 & November 7 & 1.24 & 1.66 \\
\hline 52 & Pozo Valle \#6 & May 13 & 6.37 & November 7 & 3.25 & 3.12 \\
\hline 53 & Port Authority Well & August 1 & 3.47 & November 7 & 2.29 & 1.18 \\
\hline
\end{tabular}

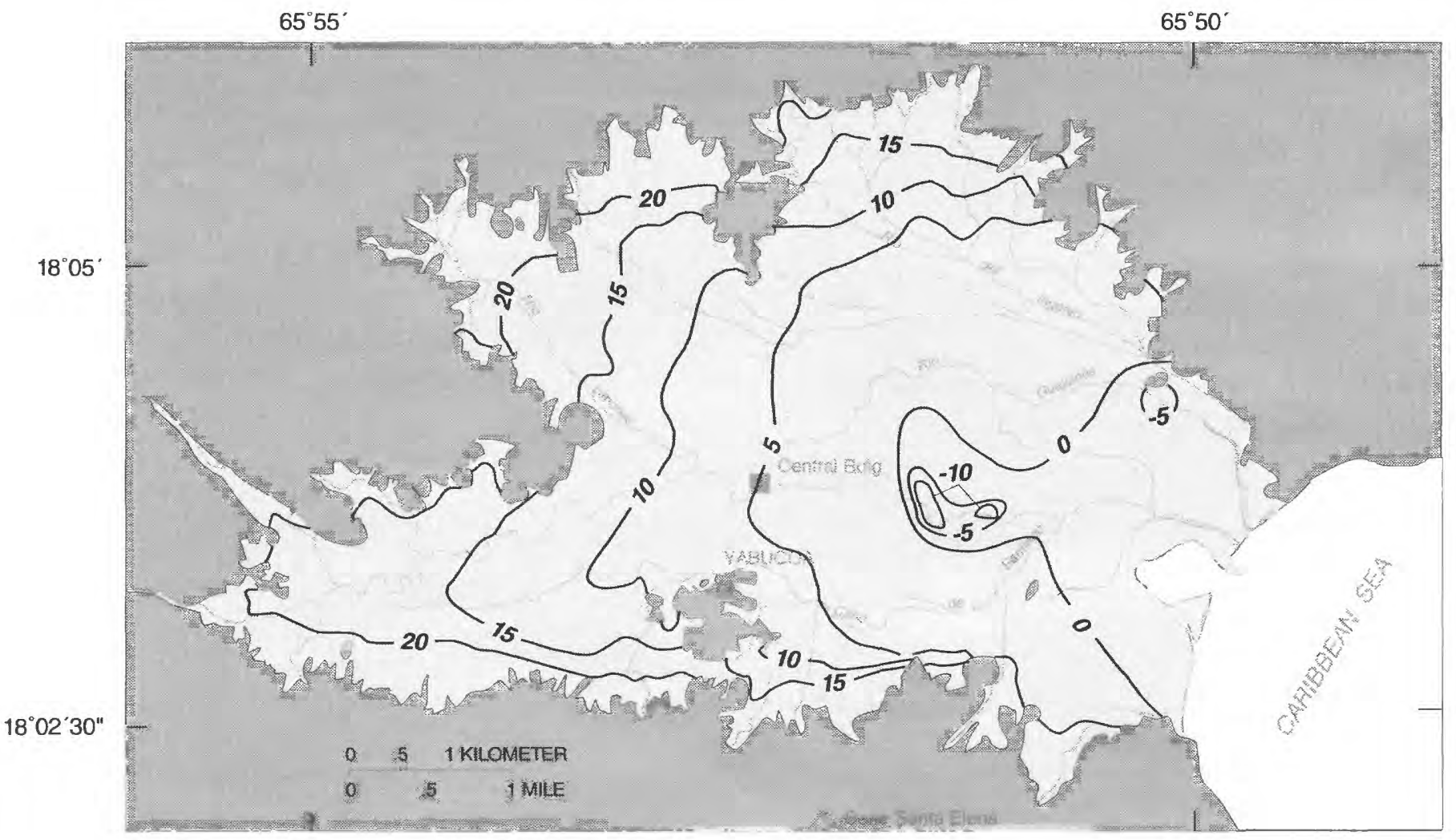

EXPLANATION

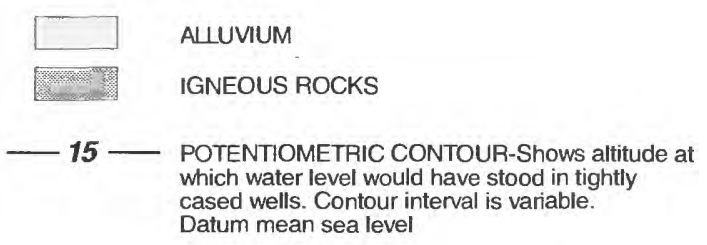

Figure 6. Potentiometric-surface map of the Valle de Yabucoa alluvial aquifer, Puerto Rico, July 1990. 
Based on the 21 stream discharge measurements (see table 16 and fig. 7), there is no significant exchange of water between the aquifer and the streams and rivers that flow above it. The amount of water flowing across the middle of the valley (sites 6, 7, 24, $25,36,40$, and 46 ) is within 1 percent of the amount that flows into the ocean (sites 38 and 48). For flowing streams to cross a cone of depression with no measurable effect on the streams or on the cone of depression indicates that there is no hydraulic connection between the surface- and ground-water systems.
Downstream of its confluence with the Río Limones, the Río Guayanés transported 75 percent of the surface water in the valley on the day of the seepage run. The Río Guayanés, to within the errors of measurement, probably has little or no exchange of water with the aquifer. The uncertainty of the conservation of mass calculations is increased by the fact that, on the day of the seepage run, the river stage, as measured at the vehicular bridge below Central Roig, fell $18 \mathrm{~mm}$ in 3.4 hours during the afternoon.

Table 16. Stream discharge data at selected sites in the Valle de Yabucoa, Puerto Rico on July 5, 1990 $\left[\mathrm{m}^{3} / \mathrm{s}\right.$, cubic meters per second; nd, not determined]

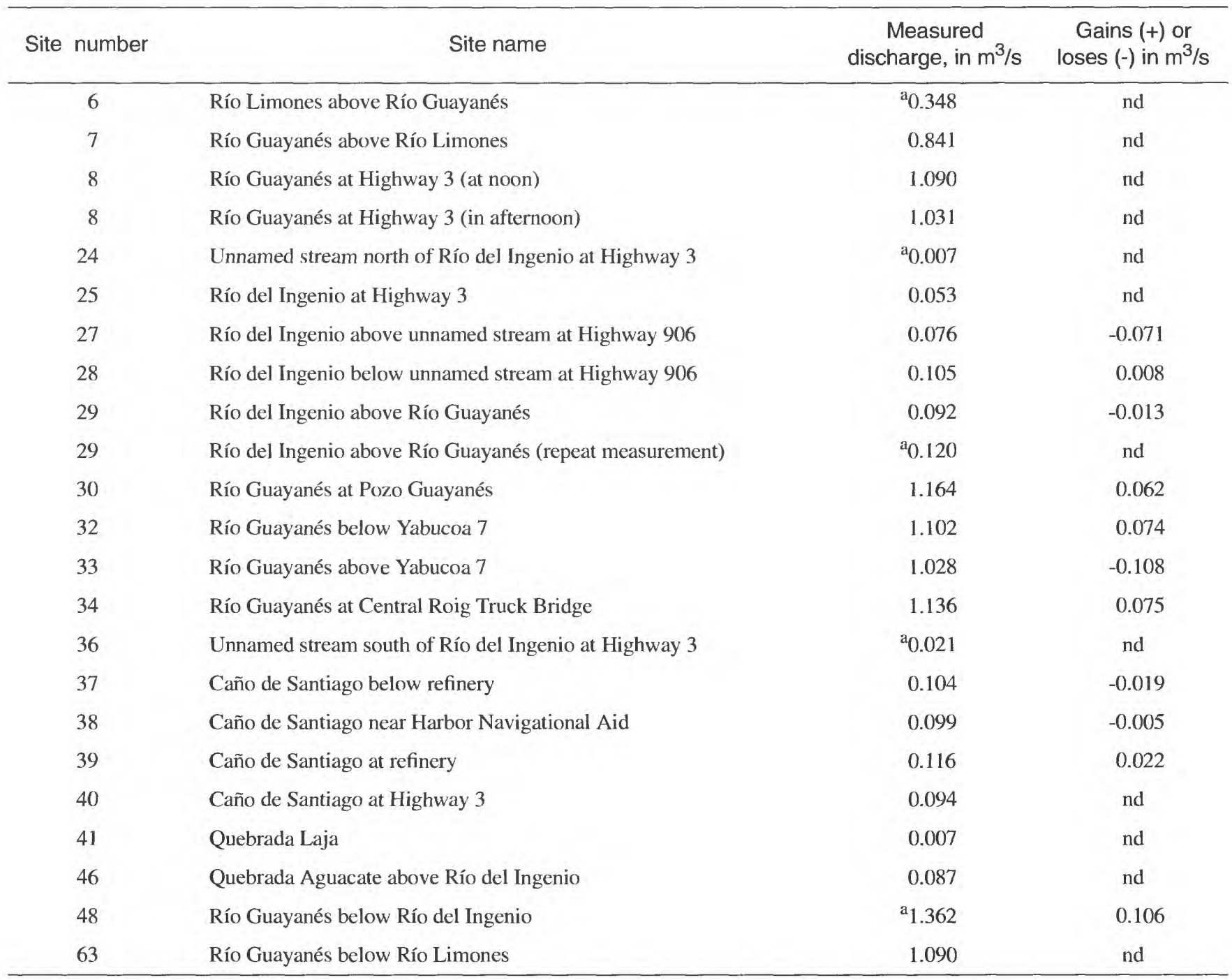

\footnotetext{
a Poor measurement with an error of more than 8 percent.
} 


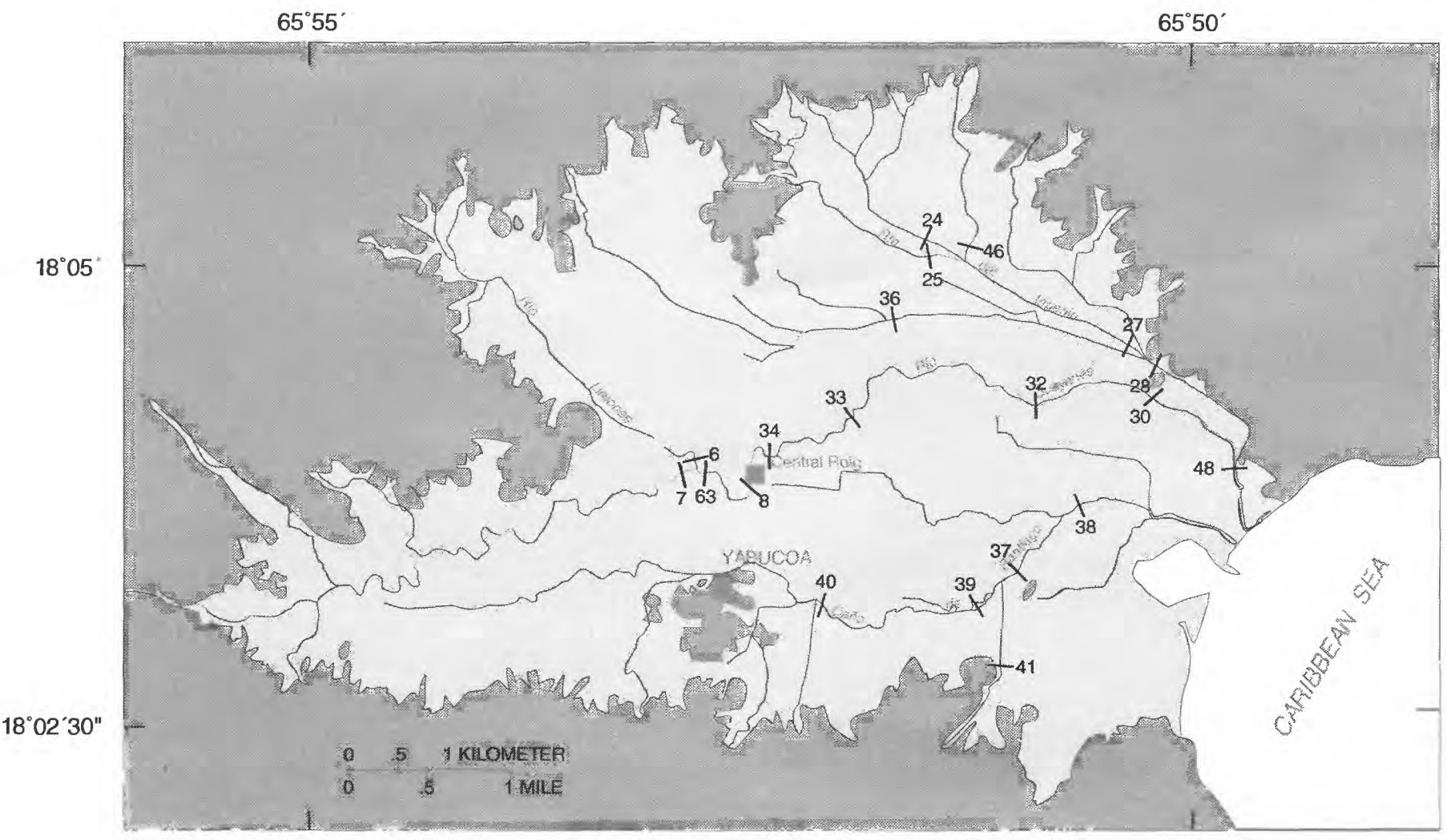

EXPLANATION

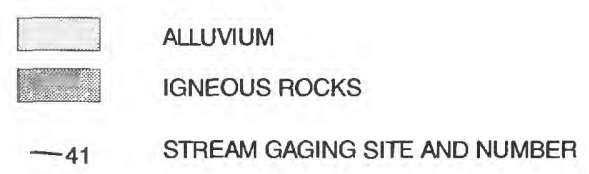

Figure 7. Location of the stream sites at which discharge measurements were made on July 5, 1990, in the Valle de Yabucoa, Puerto Rico.

The July 1990 potentiometric-surface map (fig. 6) can be compared with the pre-development potentiometric-surface (fig. 3) map from Anders (1971, p. 32). During July 1990 , the largest cone of depression is L-shaped and centered over the wells that provide water to the refinery. A second, smaller cone is centered around the public supply well that is north of the Río Guayanés.

Under these conditions active saline-water encroachment into the alluvial aquifer could be occurring. The coalesced cones of depression from the pumping wells appear to have migrated to the ocean. Under these conditions, eventually saline water would likely arrive at the production wells.

With the post-1990 reduction of pumping for the refinery and the subsequent observed rise in the potentiometric surface at the deep observation well and other wells in the vicinity, a ground-water divide separating the ocean from the pumping wells has probably developed. If this is the case, the divide would likely prevent further inland migration of the saline water. 


\section{GEOCHEMISTRY OF THE VALLE DE YABUCOA ALLUVIAL AQUIFER}

\section{Iron and Manganese Chemistry}

The results of the water-quality analyses are listed in table 17. Measured iron concentrations in the Valle de Yabucoa alluvial aquifer ranged from less than 0.003 to $28 \mathrm{mg} / \mathrm{L}$, and manganese concentrations ranged from 0.016 to $3.6 \mathrm{mg} / \mathrm{L}$. Although the elevated iron and manganese concentrations in the aquifer pose no health threat, they frequently exceed secondary standards for drinking water established by the U.S. Environmental Protection Agency of $0.3 \mathrm{mg} / \mathrm{L}$ for iron and $0.05 \mathrm{mg} / \mathrm{L}$ for manganese (U.S. House of Representatives, 1996).

Thermodynamics, including aqueous- and solidphase equilibria and oxidation and reduction (redox) reactions, and kinetics are the geochemical processes that control the distribution of iron and manganese in ground water. The oxidation states of iron and manganese of hydrogeological significance are $\mathrm{Fe}^{2+}$, $\mathrm{Fe}^{3+}, \mathrm{Mn}^{2+}$, and $\mathrm{Mn}^{4+}$. The theoretical stable ranges of iron and manganese ions, oxides, and hydroxides as a function of $\mathrm{Eh}$ and $\mathrm{pH}$ are shown in figure 8 . Oxidized iron, $\mathrm{Fe}^{3+}$, is the dominant iron ion in solution only below a $\mathrm{pH}$ of about 3 ; oxidized manganese, $\mathrm{Mn}^{4+}$, is never the dominant manganese ion in solution. The reduced species, $\mathrm{Fe}^{2+}$ and $\mathrm{Mn}^{2+}$, are the dominant hydrated ions in solution in the Eh and $\mathrm{pH}$ range of natural waters. In much of the Eh and $\mathrm{pH}$ range of natural waters $\mathrm{Fe}^{3+}$ and $\mathrm{Mn}^{4+}$ form insoluble oxides or hydroxides. The $\mathrm{Mn}^{2+}$ ion is thermodynamically stable across a wider Eh-pH range than is the $\mathrm{Fe}^{2+}$ ion, as shown in figure 8 .

Consequently, the $\mathrm{Mn}^{2+}$ ion remains in solution in aqueous environments in which $\mathrm{Fe}^{2+}$ is oxidized to $\mathrm{Fe}^{3+}$ and precipitated as $\mathrm{Fe}(\mathrm{OH})_{3}$.

The Eh, $\mathrm{pH}$, and iron and manganese concentrations for water samples from the Valle de Yabucoa alluvial aquifer are plotted in figure 8 and listed in table 18. All of these samples are from wells drilled exclusively for monitoring purposes during this investigation. These chemical analyses agree with the theoretical predictions shown in the Eh-pH diagram. All of the water compositions that fall in the stability field of the $\mathrm{Fe}^{2+}$ ion have iron concentrations greater than $10 \mathrm{mg} / \mathrm{L}$, whereas all the water compositions that

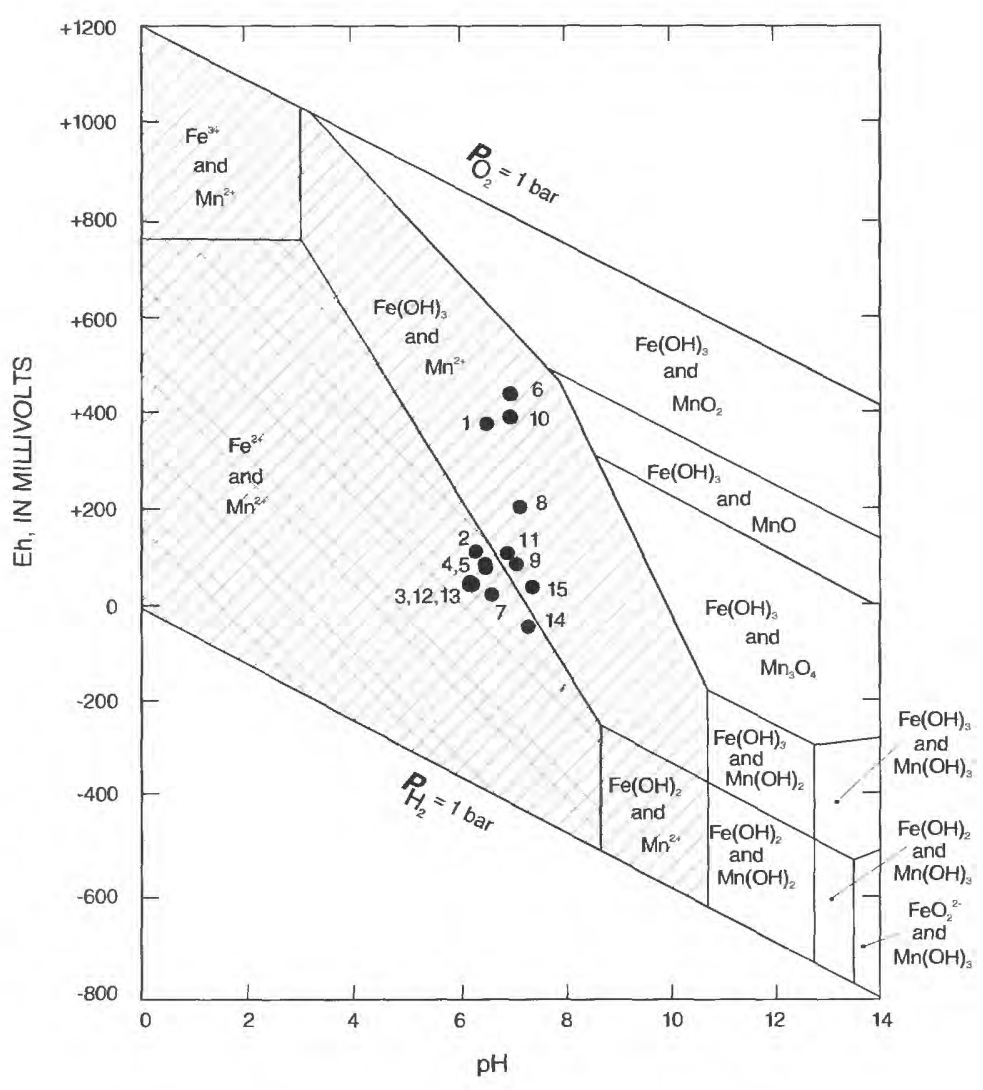

Figure 8. Eh-pH stability diagram for ferromagnesian oxides showing the Eh and $\mathrm{pH}$ of 15 ground-water samples from the Valle de Yabucoa alluvial aquifer, Puerto Rico. Iron and Manganese activities of $10^{-6}$ are assumed for the construction of the Eh-pH diagram. This diagram assumes that $\mathrm{Fe}(\mathrm{OH})_{3}$ is the stable phase for the $\mathrm{Fe}$ (III) precipitate.

fall in the stability field for $\mathrm{Fe}(\mathrm{OH})_{3}$ have iron concentrations that are less than $0.2 \mathrm{mg} / \mathrm{L}$.

None of the samples plotted in figure 8 have Eh-pH combinations that plot within the stability field of $\mathrm{MnO}_{2}$; however, it is possible that in highproduction wells the redox potential is sufficiently elevated as a result of oxygenation and that the water composition would plot within the stability field of manganese dioxide. If this were the case then the $\mathrm{Mn}^{2+}$ ion should oxidize and precipitate as $\mathrm{MnO}_{2}$. However, the kinetics of this reaction are sufficiently slow that precipitation would probably not occur until after the water was pumped from the well. Hem (1985) report that iron oxidation occurs on the order of minutes, whereas manganese oxidation requires several hours to a day under commonly encountered ground-water conditions. Accordingly, given the same environment, iron will be oxidized more rapidly than manganese. 


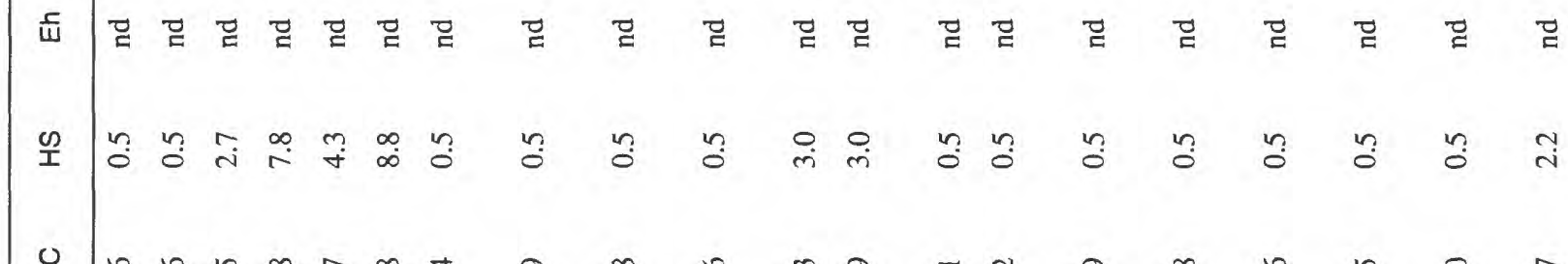

O

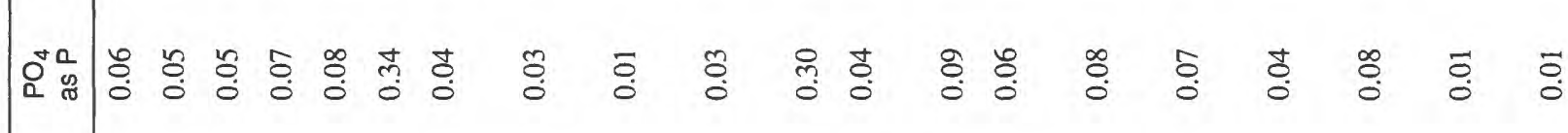

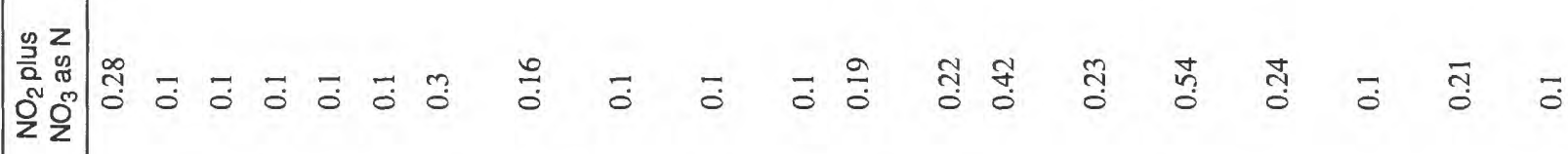

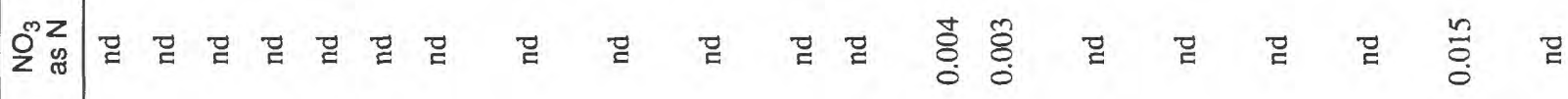

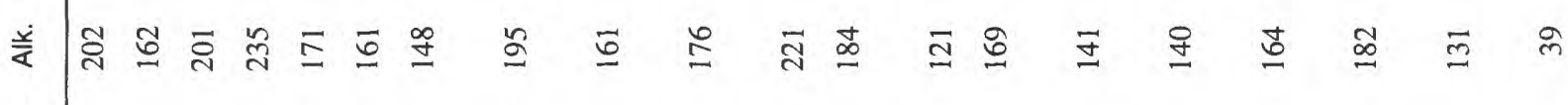

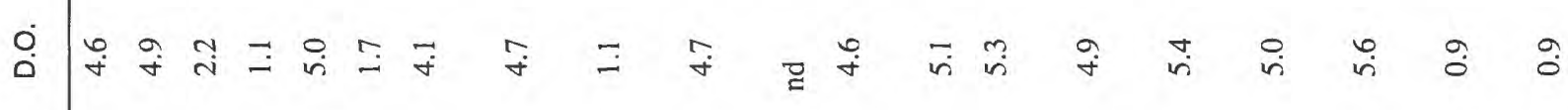
ن

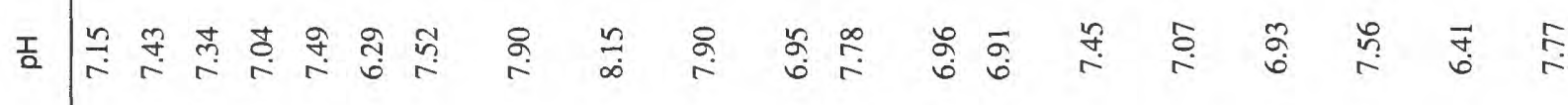
$\vdash$

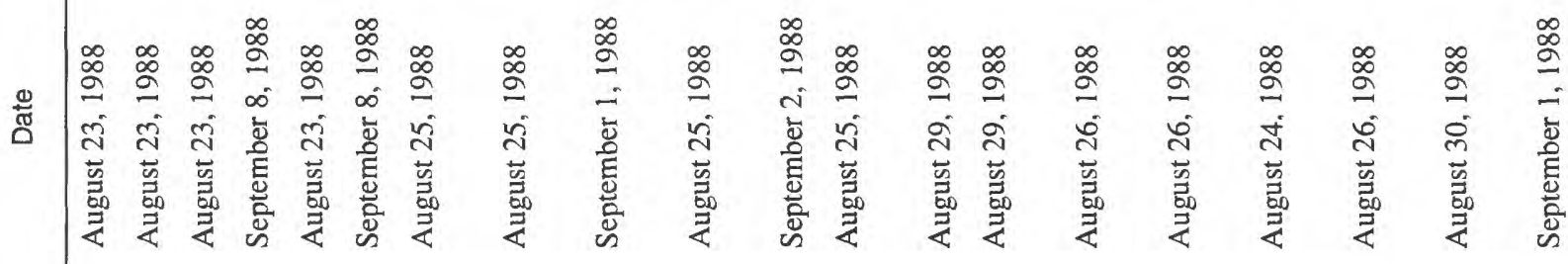

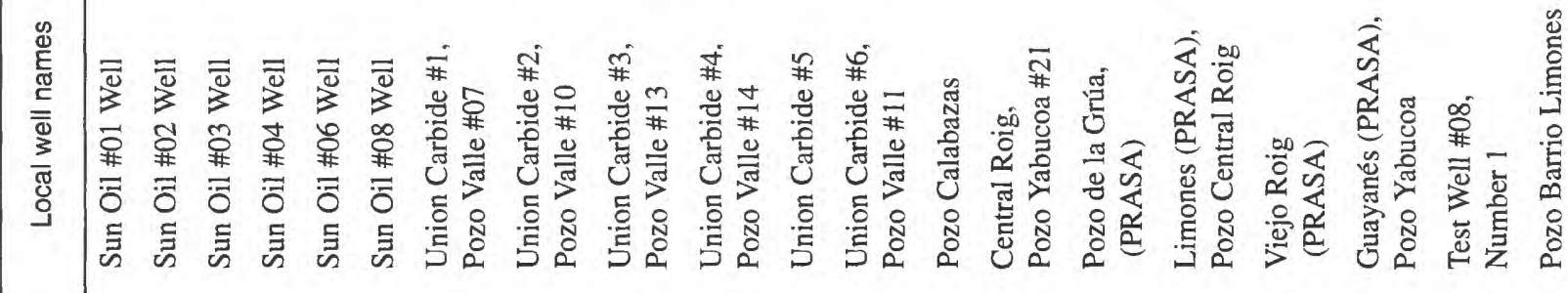

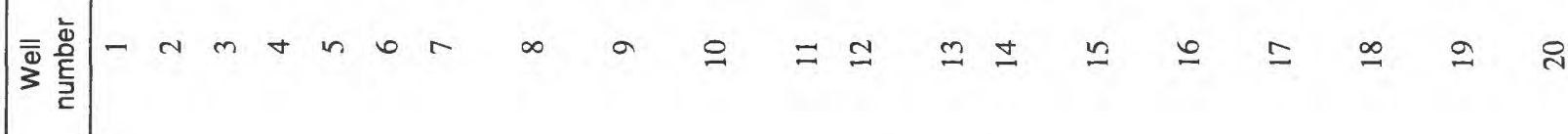




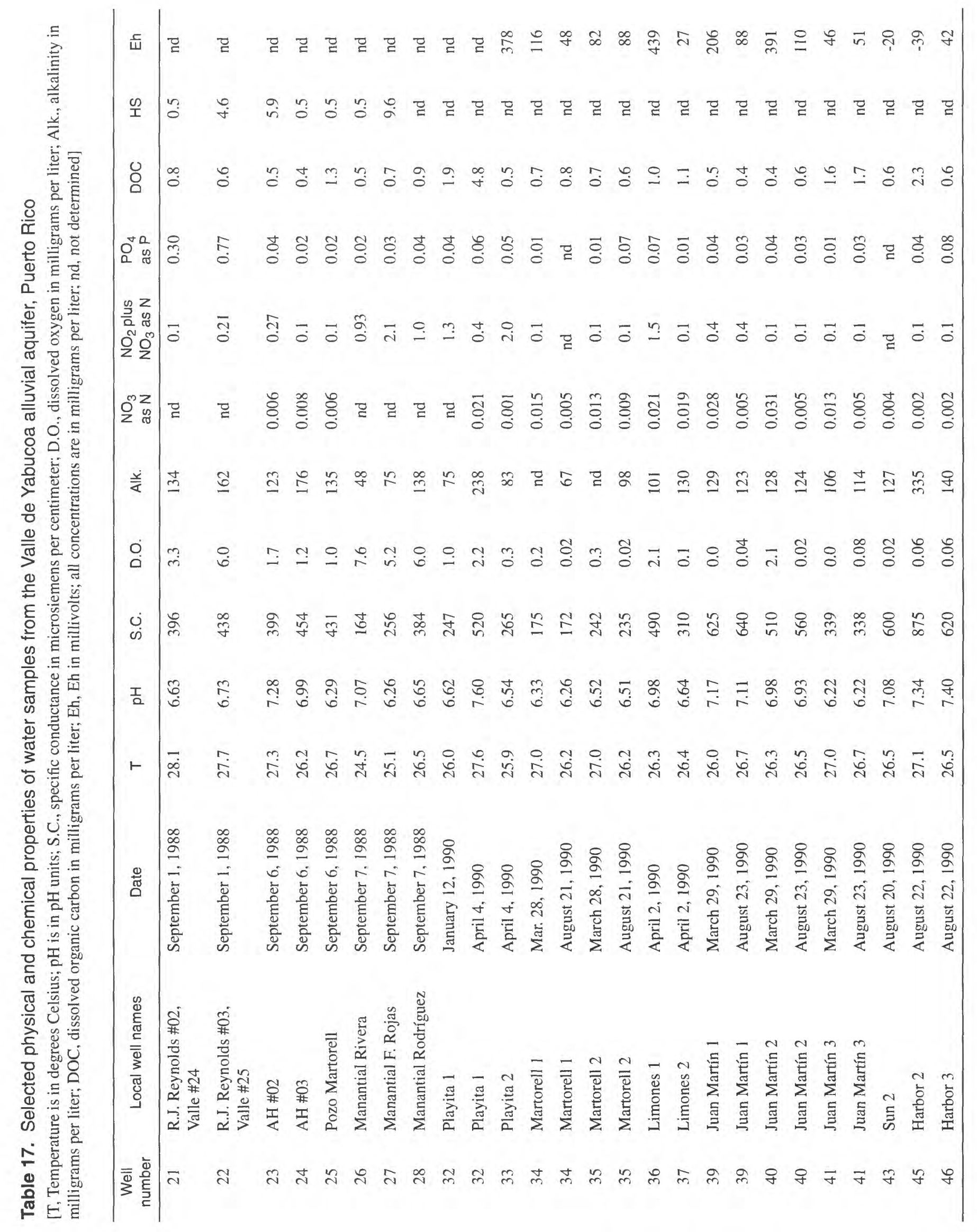




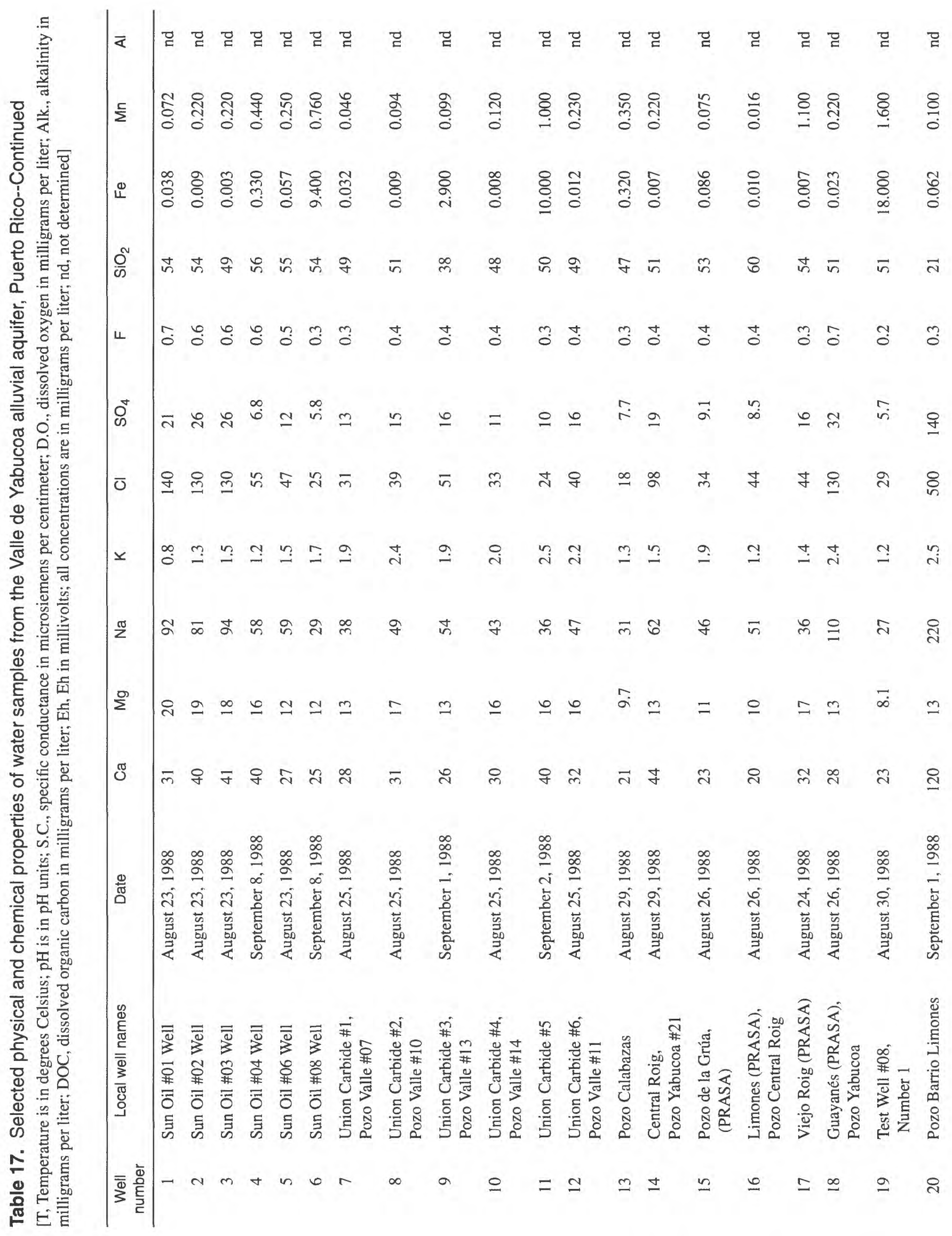




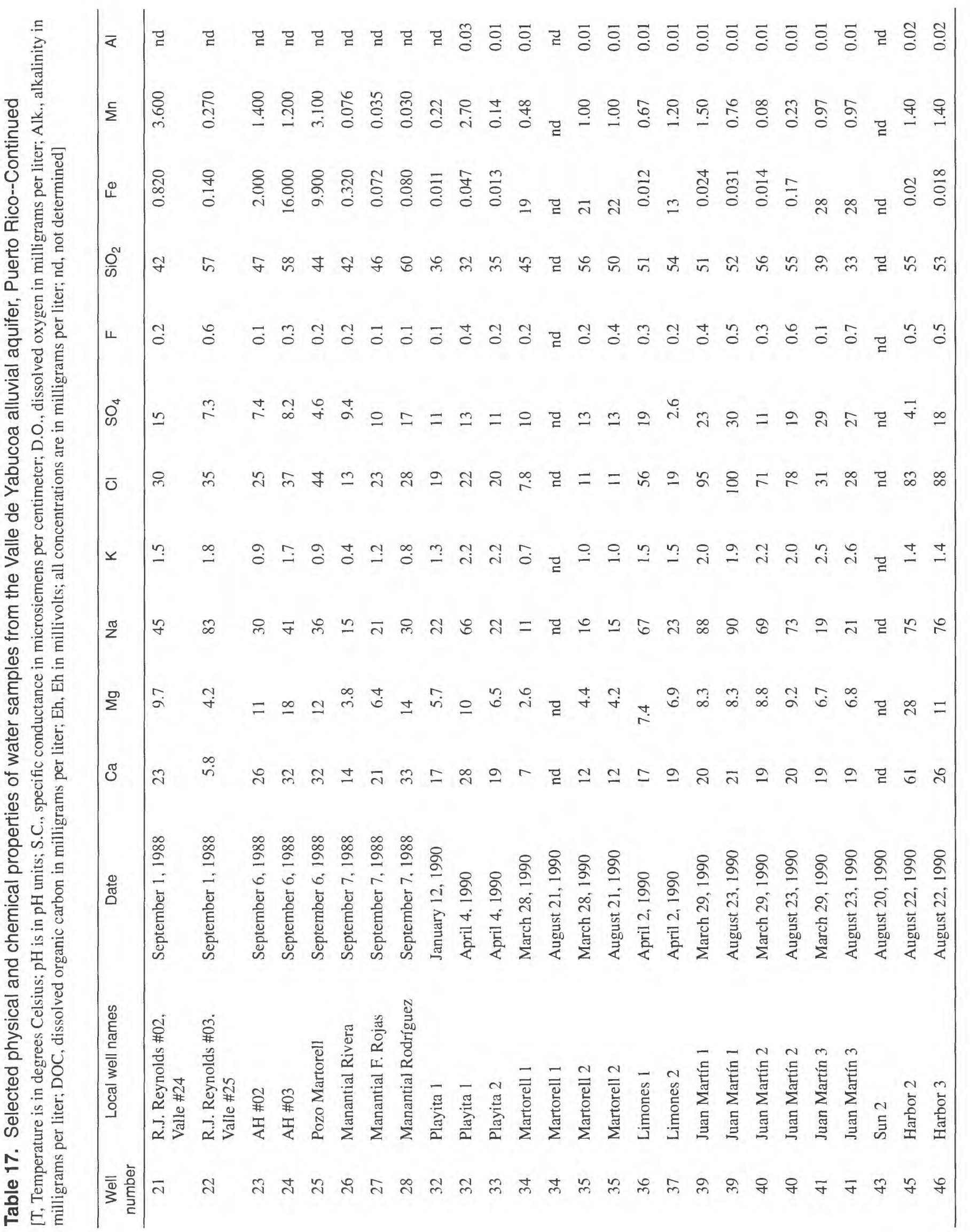


Table 18. Values for $\mathrm{Eh}, \mathrm{pH}$, and iron and manganese concentrations for water samples collected from the Valle de Yabucoa, Puerto Rico and plotted in figure 8

\begin{tabular}{cllcccc}
\hline $\begin{array}{c}\text { Sample } \\
\text { number in } \\
\text { figure 8 }\end{array}$ & Well name & \multicolumn{1}{c}{ Date } & $\mathrm{pH}$ & $\begin{array}{c}\text { Eh, in } \\
\text { millivolts }\end{array}$ & $\begin{array}{c}\text { Iron, in } \\
\text { milligrams } \\
\text { per liter }\end{array}$ & $\begin{array}{c}\text { Manganese, } \\
\text { in milligrams } \\
\text { per liter }\end{array}$ \\
\hline 1 & Playita 2 & April 4, 1990 & 6.54 & 378 & 0.013 & 0.14 \\
2 & Martorell 1 & March 28, 1990 & 6.33 & 116 & 19 & 0.48 \\
3 & Martorell 1 & August 21, 1990 & 6.26 & 48 & 19 & 0.47 \\
4 & Martorell 2 & March 28, 1990 & 6.52 & 82 & 21 & 1.00 \\
5 & Martorell 2 & August 21, 1990 & 6.51 & 88 & 22 & 1.00 \\
6 & Limones 1 & April 2, 1990 & 6.98 & 439 & 0.012 & 0.67 \\
7 & Limones 2 & April 2, 1990 & 6.64 & 27 & 13 & 1.20 \\
8 & Juan Martín 1 & March 29, 1990 & 7.17 & 206 & 0.024 & 1.50 \\
9 & Juan Martín 1 & August 23, 1990 & 7.11 & 88 & 0.031 & 0.76 \\
10 & Juan Martín 2 & March 29, 1990 & 6.98 & 391 & 0.014 & 0.081 \\
11 & Juan Martín 2 & August 23, 1990 & 6.93 & 110 & 0.17 & 0.23 \\
12 & Juan Martín 3 & March 29, 1990 & 6.22 & 46 & 28 & 0.97 \\
13 & Juan Martín 3 & August 23, 1990 & 6.22 & 51 & 28 & 0.97 \\
14 & Harbor 2 & August 22, 1990 & 7.34 & -39 & 0.020 & 1.40 \\
15 & Harbor 3 & August 22, 1990 & 7.40 & 42 & 0.018 & 1.40 \\
\hline
\end{tabular}

A careful analysis of the data reveals that high-production industrial and public-supply wells yielded water with relatively low iron and manganese concentrations, whereas abandoned and small private wells producing relatively small amounts of water yielded water with higher iron and manganese concentrations. The histograms in figure 9 illustrate the distribution of iron and manganese within both data subsets. The data in figure 9 were logarithmically transformed, and the resulting distributions in each of the histograms are approximately normal in the case of the abandoned and small private wells. Because the data are lognormally distributed, the geometric mean is presented in table 19 to represent the best measure of central tendency.
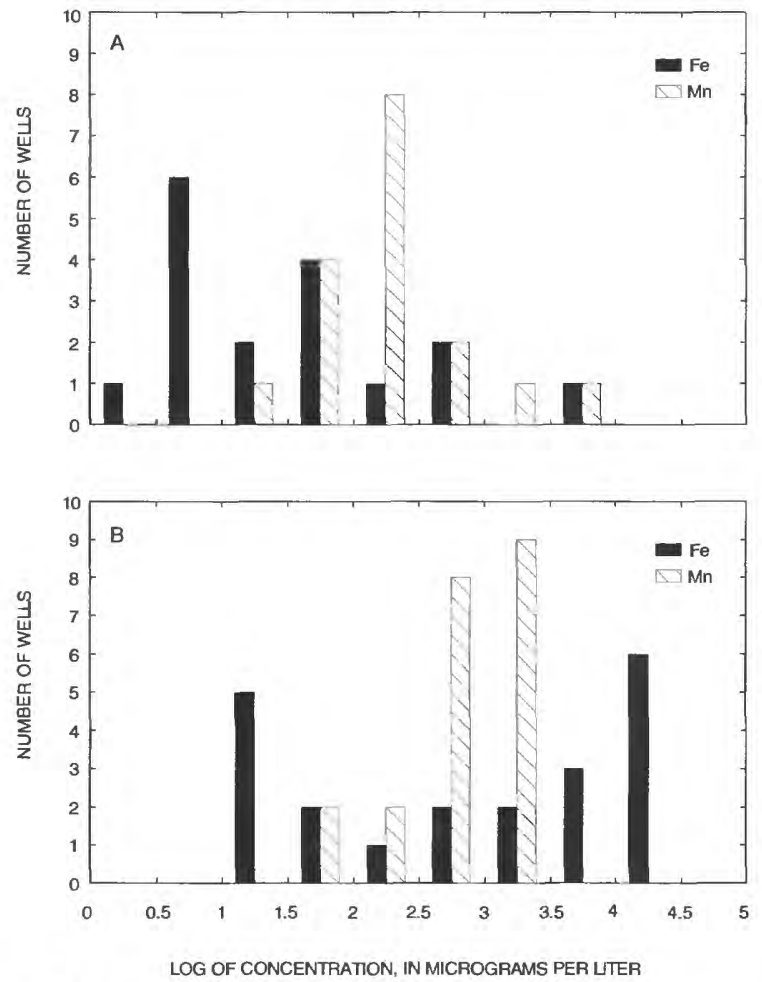

Figure 9. Distribution of iron and manganese concentrations in water pumped from $(A)$ abandoned and small private wells and from $(B)$ high-production industrial and public-supply wells. 
The discrepancy in iron and manganese concentrations between the two types of wells indicate that well pumping characteristics can effect the magnitude of iron and manganese concentrations. The most likely explanation for this finding is that the wells producing large volumes of water are causing ground-water aeration in the vicinity of the pumping horizon. The aeration of ground water may result from the cascading of ground water inside well bores having two or more screened intervals or the rapid flow of ground water through the gravel pack surrounding the well bore. The aeration of ground water by one or more of these processes is thought to increase the redox potential in the immediate vicinity of the screened horizon to the point at which the oxidation of iron and, to a lesser degree, the oxidation of manganese can occur, resulting in the precipitation of the corresponding hydroxides in the aquifer, well, lift pipe, and distribution system.

The data in table 19 confirm the thermodynamic and kinetic expectations; for artificially oxygenated water (from large, continuous-production industrial and water-supply wells), the mean iron concentration is about 20 times lower than the mean iron concentration of un-oxygenated well water samples (from abandoned wells and wells with low production) whereas the mean manganese concentration of artificially oxygenated ground water samples was only about 3 times lower than in anoxic water samples.

Based on the findings discussed above, all iron and manganese concentrations measured in water samples collected from large industrial and watersupply wells are considered as nonrepresentative of actual, aquifer conditions. In addition, the March 1990 chemical analyses of water from the Martorell 1, Martorell 2, Juan Martín 1, Juan Martín 2, and Juan Martín 3 wells may also not represent actual aquifer conditions because the samples were taken only a few days after the wells had been developed with compressed air.

The distribution of iron and manganese, based on the chemical analyses of water from wells which do not appear to significantly oxygenate ground water, is depicted in figure 10 and figure 11. Low iron concentrations were measured near the boundary of the aquifer, where recharge occurs. Low iron concentrations were also measured in water from three shallow wells in the central portion of the aquifer, Limones 1, Juan Martín 1, and Juan Martín 2; however, at these sites the iron concentration increased greatly with depth. To better represent average aquifer conditions, the data from these shallow wells are not presented in figure 10 , instead the data from the deep wells, Limones 2 and Juan Martín 3 are presented in figure 10.

The iron concentration in the ground water increases rapidly from the low concentrations observed near the boundaries of the aquifer and in shallow wells. After this rapid increase the concentrations then decrease near the center of the valley. Water from wells in the center of the valley with low iron concentrations frequently has a slight hydrogen sulfide odor. If hydrogen sulfide is present in the water, the iron has probably precipitated out of the ground water as an iron sulfide mineral.

Table 19. Geometric mean concentrations of iron and manganese in water produced from high-production industrial and municipal water-supply wells (high) and abandoned and low production private wells (low) in the Valle de Yabucoa, Puerto Rico

[mg/L, milligrams per liter]

\begin{tabular}{ccccc}
\hline $\begin{array}{c}\text { Production } \\
\text { level }\end{array}$ & $\begin{array}{c}\text { Iron concentration } \\
\text { range }(\mathrm{mg} / \mathrm{L})\end{array}$ & $\begin{array}{c}\text { Geometric mean of iron } \\
\text { concentration }(\mathrm{mg} / \mathrm{L})\end{array}$ & $\begin{array}{c}\text { Manganese } \\
\text { concentration range } \\
(\mathrm{mg} / \mathrm{L})\end{array}$ & $\begin{array}{c}\text { Geometric mean of } \\
\text { manganese concentration } \\
(\mathrm{mg} / \mathrm{L})\end{array}$ \\
\hline High & less than 0.003 to 10 & 0.038 & 0.02 to 3.6 & 0.207 \\
Low & 0.012 to 28 & 0.831 & 0.01 to 3.1 & 0.712 \\
\hline
\end{tabular}




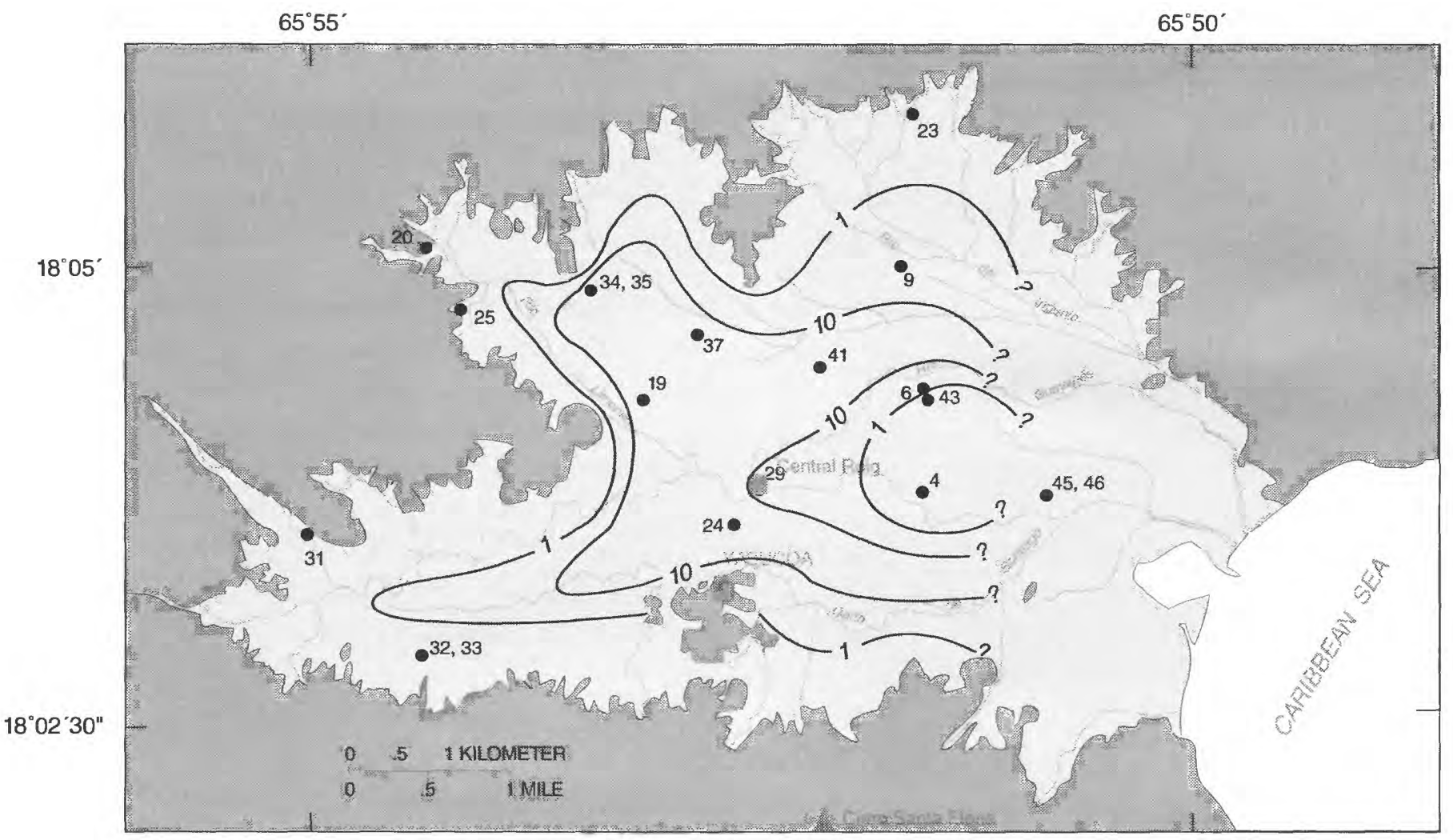

EXPLANATION

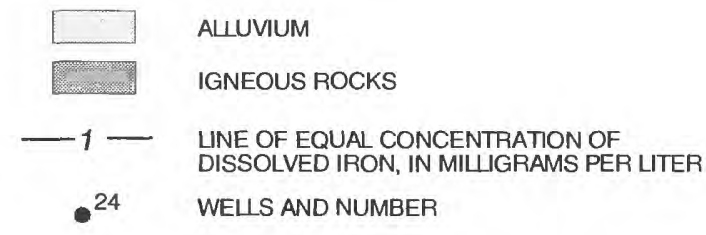

Figure 10. Distribution of iron in water in the Valle de Yabucoa alluvial aquifer, Puerto Rico.

The geographic distribution of manganese (fig. 11 ) is similar to that of iron. High manganese concentrations were measured in the center of the valley, and lower concentrations occurred in the recharge zone. The variation in manganese concentration is considerably less than the variation of iron concentration. Manganese concentrations are somewhat lower in the three down-gradient wells: Sun Oil \#4 Well, Sun Oil \#8, and Union Carbide \#3 (numbers 4, 6, and 9 in table 3 and fig. 4).
The actual three-dimensional distribution of both iron and manganese is more complicated than indicated on figures 10 and 11 . The observation wells at the Martorell, Limones, and Juan Martín well sites were carefully constructed to be open to only certain depths in the aquifer. The chemical analyses (table 18) clearly indicate that Eh decreases with depth, whereas iron and manganese increase with depth in the aquifer. Similar chemical changes with depth probably occur throughout the aquifer, but detailed information on these changes with depth is only available only for these three well sites. 

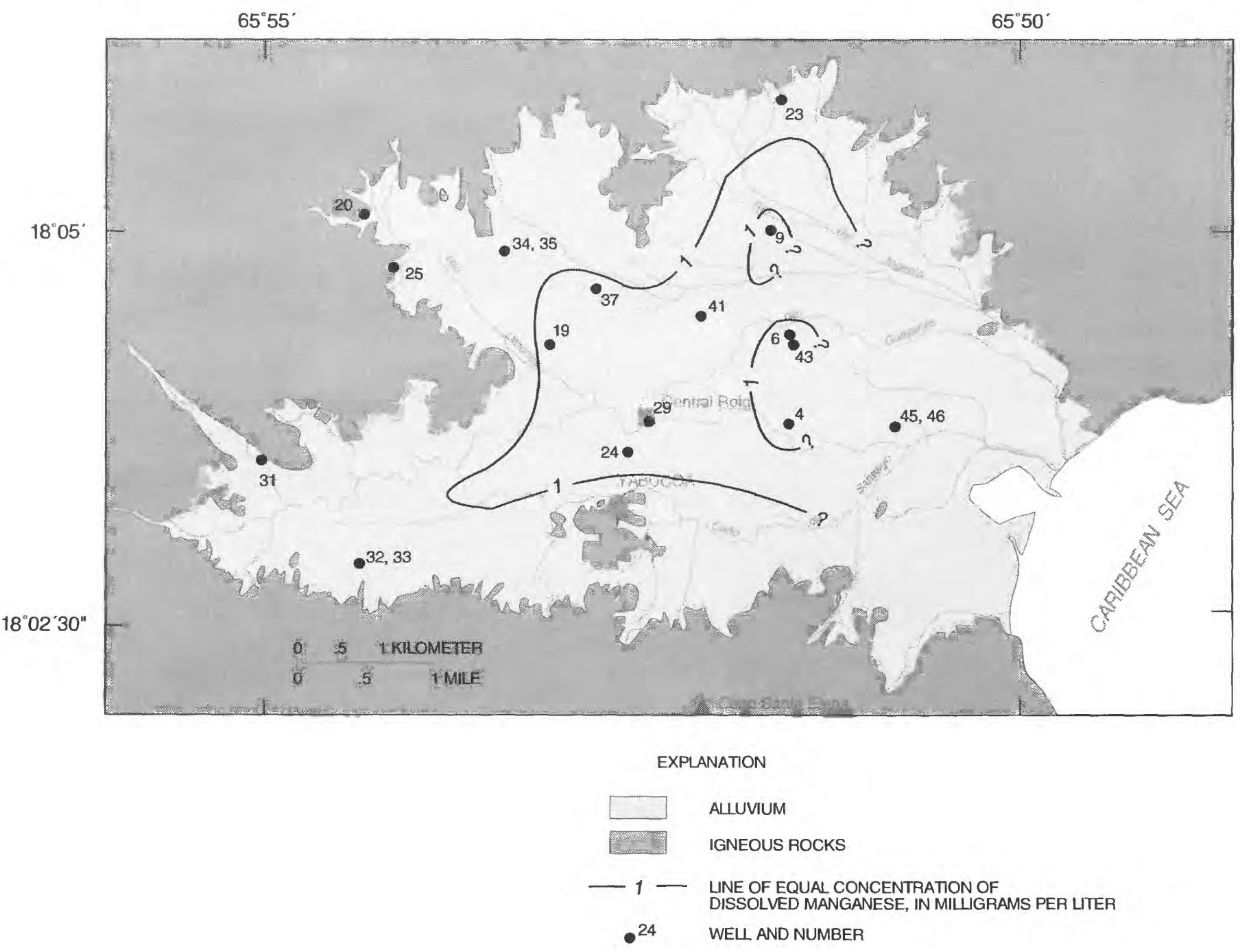

Figure 11. Distribution of manganese in water in the Valle de Yabucoa alluvial aquifer, Puerto Rico.

\section{Sources and Sinks of Iron and Manganese}

Electron and optical microscopy, energy dispersive spectroscopy, and $\mathrm{x}$-ray diffraction have identified several iron-containing minerals that are weathering and releasing iron into the ground water. These minerals include plagioclase, calcian amphibole, biotite, magnetite, hematite, ilmenite, and iron oxide coatings on grains. Mechanisms of iron introduction into the ground water include both the dissolution of ferrous iron-bearing minerals and the reduction of ferric oxides. Reducing conditions [Eh ranges from +439 to -30 millivolts], in the majority of the aquifer maintain much of the ground water within the region of thermodynamic stability of the $\mathrm{Fe}^{2+}$ ion, which enables the dissolution of iron from the iron bearing minerals in the aquifer. Loss of ferrous iron from these minerals is probably responsible for most of the observed elevated iron concentrations.

The largest contributor of ferrous iron to the ground water appears to be an iron oxide phase (probably maghemite, $\gamma-\mathrm{Fe}_{2} \mathrm{O}_{3}$, an alteration of magnetite). Petrographic observations indicate that maghemite has been removed leaving behind a skeleton of hematite on the (111) planes of the original magnetite crystal. This agrees with the saturations indexes calculated by the WATEQ4F water-quality computer model (Ball and Nordstrom, 1991). The results from WATEQ4F model indicates that the 
reducing ground water in most of the aquifer is slightly under saturation with maghemite and oversaturated with both magnetite and hematite.

Only two mineral phases in the aquifer have been found to contain detectable manganese; amphibole and ilmenite. Trace amounts of manganese were found in the amphibole; however, the low concentrations and the fact that amphibole is not extensively corroded make it unlikely that this mineral is the primary source of the relatively high manganese concentrations found in the water. Ilmenite, $(\mathrm{Fe}, \mathrm{Mn}) \mathrm{TiO}_{3}$, constitutes approximately 0.2 percent of the sediment, contains from 0 to 20 percent manganese substituting for iron in a solid solution with pyrophanite, $\mathrm{MnTiO}_{3}$, and is probably the sole significant source of manganese. Individual ilmenite grains contain patches and streaks of leucoxene (a combination of rutile, $\mathrm{TiO}_{2}$; anatase, $\mathrm{TiO}_{2}$; and sphene, $\mathrm{CaTiO}\left(\mathrm{SiO}_{4}\right)$ ), indicating that leaching of iron and manganese from the original ilmenite has resulted in the formation of the iron and manganese-free alteration product and the release of the manganous and ferrous ions into the reducing ground water without oxidation or reduction reactions. The liberation of iron and manganese during the progressive alteration of ilmenite to leucoxene (possibly including the intermediate alteration product pseudo-rutile) has been reported by other workers (Morad and Aldahan, 1985; Anand and Gilkes, 1984).

Only one authigenic mineral appears to be forming in the aquifer and serving as a sink for iron or manganese. Some iron is removed from the ground water by the precipitation of 2- to 5-mm euhedral crystals of chalcopyrite.

A mass-balance geochemical model was derived using methods described by Plummer and others (1983) with the aid of the NETPATH computer program (Plummer and others, 1991) to account for the chemical evolution of water in composition the aquifer. In the mass-balance model andesine, amphibole, ilmenite, and biotite dissolve; organic carbon is oxidized; dissolved carbon dioxide gas is supplied from an external source; calcium is exchanged for sodium; and silica, goethite, kaolinite, and chalcopyrite are precipitated. Results of geochemical mass-balance modeling of the water chemistry agree with the optical and electron microscopy data (Troester and others, 1990a; b).

\section{Saline Intrusion}

As ground water flows through the Valle de Yabucoa alluvial aquifer to the sea, chemical reactions between the water and the aquifer slowly increase the dissolved solids in the water and change the chemical characteristics of the water. Specific conductance can be readily measured in the field, and dissolved-solids concentrations (in milligrams per liter) can be estimated by multiplying the specific conductance value (in microsiemens per centimeter) by 0.59 . For example, $12,000 \mu \mathrm{S} / \mathrm{cm}$ is approximately equal to about 7,000 $\mathrm{mg} / \mathrm{L}$ dissolved solids. For reference, typical ocean water has a dissolved-solids concentration of about $34,000 \mathrm{mg} / \mathrm{L}$.

The specific conductance measurements of the water in the aquifer ranged from less than $200 \mu \mathrm{S} / \mathrm{cm}$ in a shallow well at the western edge of the aquifer (Martorell 1, table 17) to more than $12,000 \mu \mathrm{S} / \mathrm{cm}$ in the deep observation well (table 14). Prior to drilling the deep observation well, the maximum measured specific conductance of water in the aquifer was 875 $\mu \mathrm{S} / \mathrm{cm}$ (at the Harbor 2 well; table 17), and the measurements averaged about $500 \mu \mathrm{S} / \mathrm{cm}$. Ground water with a specific conductance value of $875 \mu \mathrm{S} / \mathrm{cm}$ typically will have a dissolved solids concentration near the U.S. Environmental Protection Agency secondary drinking water standard for total dissolved solids of $500 \mathrm{mg} / \mathrm{L}$ (U.S. House of Representatives, 1996).

All of the complete chemical analyses in table 17 are plotted in figure 12, with the exception of the three springs (numbers 25 to 28) and Pozo Barrio Limones (number 20). The ground-water chemistry of the three springs is not representative of the Valle de Yabucoa alluvial aquifer because the springs issue from the igneous rocks that surround the Valle de Yabucoa. In addition the ground-water chemistry in the one sample from the Pozo Barrio Limones does not appear to reflect the chemistry of the aquifer, which may be because this private well was not properly developed prior to sampling. 
The large arrows in figure 12 indicate the general trends in the chemistry of the aquifer. In the up-gradient portion of the aquifer the water is typically rich in calcium, magnesium, and bicarbonate. As the water moves through the aquifer and approaches the ocean, it becomes rich in sodium, potassium, and chloride. Additional details on the interpretation of Piper diagrams can be found in Piper $(1944 ; 1953)$ and Briel (1993).

Unfortunately, little time series data exist that indicate the changes in ground-water chemistry that occur as a well is effected by saline intrusion. Usually, shortly after a well has been affected the well is abandoned and, subsequently, destroyed. For example, when water from the Sun Oil \#1 well (the closest industrial supply well to the ocean) was sampled, the water had one of the highest specific conductance values measured, and the well has since been taken out of service and destroyed.

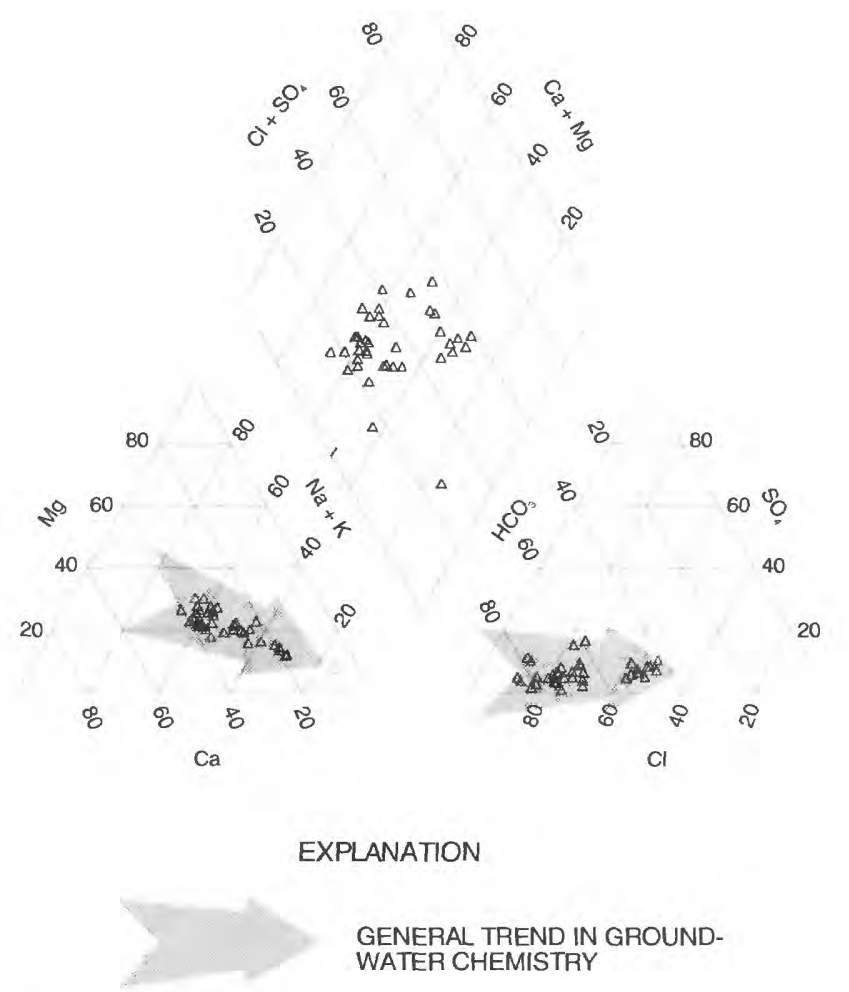

Figure 12. Piper diagram showing overall composition of sampled water in the Valle de Yabucoa alluvial aquifer, Puerto Rico.
Continued monitoring of the deep observation well may document changes in the ground-water chemistry at that site; however, the values that are listed in table 14 are approximately within the error in measuring specific conductance.

\section{RESULTS OF THE GEOPHYSICAL SURVEY}

Geophysical data were obtained at 84 sites in the Valle de Yabucoa using the TC method and at 31 sites using the TEM method. Six sets of the 84 data sets produced using the TC method were not used in this study because of interpretation problems believed to be caused by the nearby presence of scrap metal.

The apparent conductivity data produced from the TC method were analyzed and are presented in two different ways. First, some of the actual field measurements of apparent conductivity were plotted on a map of the area and contoured. Later each individual set of apparent conductivity measurements was modeled with a computer program to determine the depth to bedrock at each site. These depth-tobedrock data were then combined with other depth-tobedrock data to produce a map of the altitude of the top of the bedrock surface beneath the aquifer.

The contour map produced from the data obtained with the 40-m coil separation in the horizontal dipole $(\mathrm{H} 40)$ orientation is shown in figure 13. The map is based on 78 data points. With this coil separation and orientation, 50 percent of the signal received is from less than upper $16 \mathrm{~m}$ depth and 80 percent of the signal received is from less than $40 \mathrm{~m}$ depth.

As expected, the apparent conductivity of the ground is highest near the coast. Readings of 100 $\mathrm{mS} / \mathrm{m}$ or more are found only near the coast. The shape of both the $200 \mathrm{mS} / \mathrm{m}$ and the $100 \mathrm{mS} / \mathrm{m}$ contours are generally similar to the coastline; however, both contours are farther from the coast north of the harbor, than they are south of the harbor.

There is a large lobe of medium $(75-100 \mathrm{mS} / \mathrm{m})$ apparent conductivity extending inland north of the Caño de Santiago. This lobe of medium apparent conductivity is interpreted to be a paleochannel that 
was cut through the ridge of bedrock when sea levels were as much as $120 \mathrm{~m}$ lower than today during the last glacial maximum (Fairbanks, 1989). The medium values of apparent conductivity in this area probably represent saline water near the base of the Valle de Yabucoa alluvial aquifer. Thus the specific conductance of this water should be equal to or greater than the specific conductance of the water at the deep observation well, which averages about $12,000 \mu \mathrm{S} / \mathrm{cm}$.
The lobe of medium apparent conductivity separates two areas of low (less than $50 \mathrm{mS} / \mathrm{m}$ ) apparent conductivity, one large area west of the harbor and another smaller area north of the harbor. The area of low apparent conductivity west of the harbor corresponds to the buried Harbor Ridge discussed by Anders (1971) and shown on figure 1. The area of low apparent conductivity north of the harbor is probably another buried ridge in the bedrock topography. This second ridge was not recognized by Anders (1971) because he lacked data from this small area.

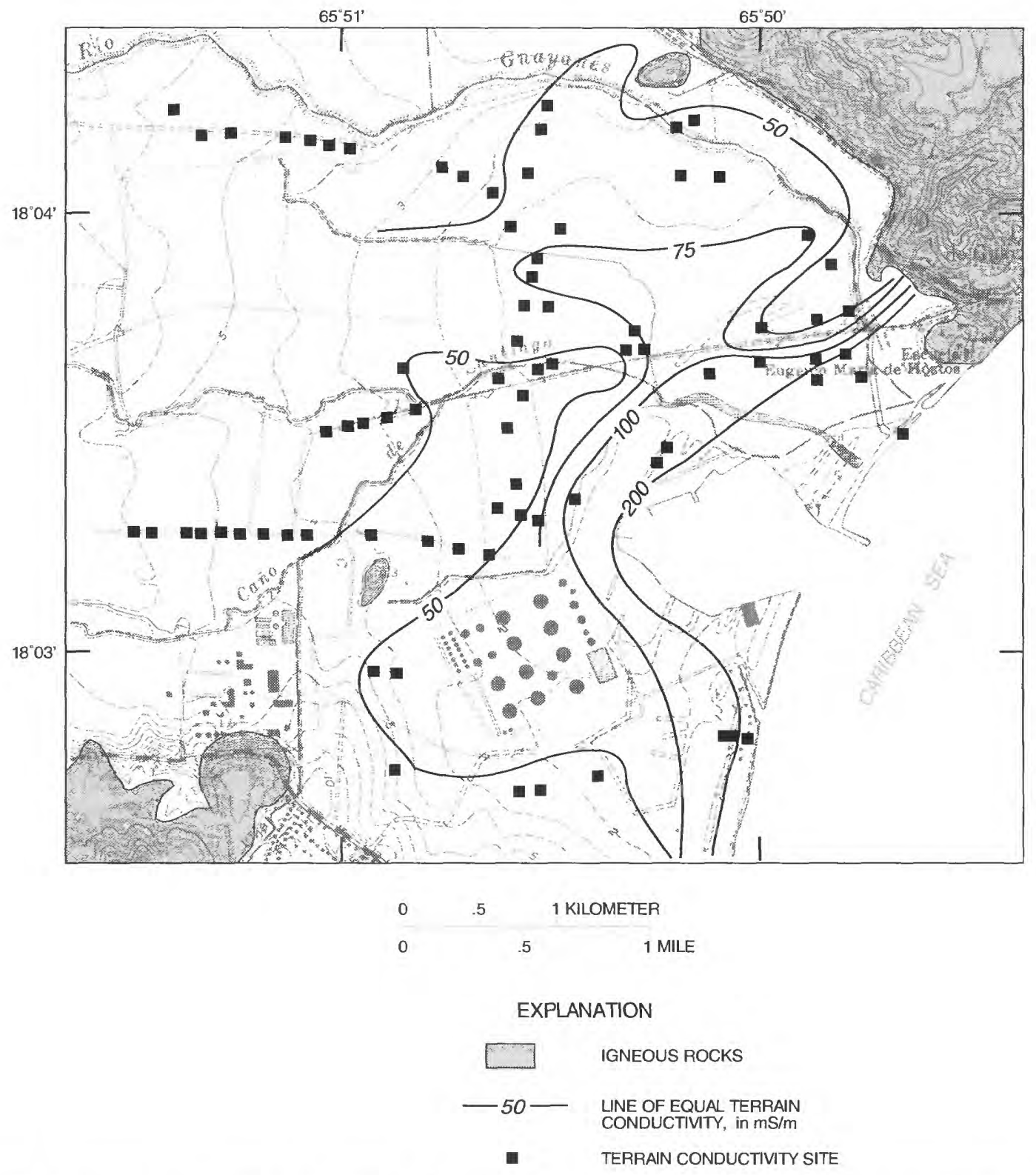

Figure 13. Apparent conductivity data from TC method using a 40-m coil separation and a horizontal dipole (H40) in the Valle de Yabucoa, Puerto Rico. 
The high values (more than $100 \mathrm{mS} / \mathrm{m}$ ) of apparent conductivity near the coast probably are caused by saline water in the alluvium east of the two buried ridges. North of the harbor, the steep gradient of apparent conductivity values indicates that the saline water ends abruptly where it abuts the bedrock ridge.

A second method of presenting the data from the TC method required the construction of geoelectric models that best fit each set of apparent conductivity measurements. This is accomplished with the EMIX34 computer program by Interpex. This program requires the operator to select an initial geoelectric model, which includes the number of layers and the thickness and connectivity of each layer. The computer program then determines the geoelectric model that best fits the apparent conductivity data by the method of inversion. The initial selection of layers and corresponding conductivities is based on knowledge of the geology of the site and an examination of the apparent conductivity data. In most cases, a number of different initial models were tried. In areas where the geology appeared to be laterally homogenous, the final model at one site was used as the starting model for adjacent sites.

For the 84 sets of data produced with the TC method, a 2-layer model was used at 44 sites, a 3-layer model at 28 sites, and at 12 sites it was not possible to find a model that fit the data well. At 6 of the 12 sites that were not modelled the apparent conductivity was above $100 \mathrm{mS} / \mathrm{m}$.

A similar procedure was used with the 31 data sets produced with the TEM method. These sites were modeled with the TEMIX47 computer program by Interpex.
The geoelectric models of the geophysical data were then interpreted based on the geologic knowledge of the valley and the available driller's log data. Conductivity ranged from 5 to $200 \mathrm{mS} / \mathrm{m}$ for unsaturated alluvium and alluvium saturated with freshwater and from 100 to $300 \mathrm{mS} / \mathrm{m}$ for alluvium saturated with saline water. The conductivity of the bedrock in the area, generally was less than $10 \mathrm{mS} / \mathrm{m}$. In parts of the study area, it was difficult distinguishing between clayey alluvium saturated with freshwater and alluvium saturated with brackish water on the basis of conductivity measurements.

The interpretation of the geoelectric models produced form the data obtained with both the TC and TEM methods and the available data from wells drilled in the lower part of the Valle de Yabucoa were used to produce a map of the altitude of the top of the bedrock underlying the aquifer (fig. 14). This map is similar to the map of altitude of the top of bedrock produce by Robison and Anders (1973, p.4), which is reproduced in this report as figure 15.

The two maps are similar, but figure 14 does provide more detailed information in the crucial area near the coast. Figure 14 clearly shows a paleochannel incised in the bedrock just north of and roughly parallel to the Caño de Santiago. This paleochannel forms a narrow canyon that separates the Harbor Ridge from the buried bedrock ridge which extends from the northern side of the valley. The map indicates that in a space of less than $600 \mathrm{~m}$, the bedrockalluvium contact decreases from $50 \mathrm{~m}$ below sea level to more than $100 \mathrm{~m}$ below sea level and then increases to $45 \mathrm{~m}$ below sea level. Further inland the channel widens out. The deep observation well was drilled into the wider portion of this paleochannel. 

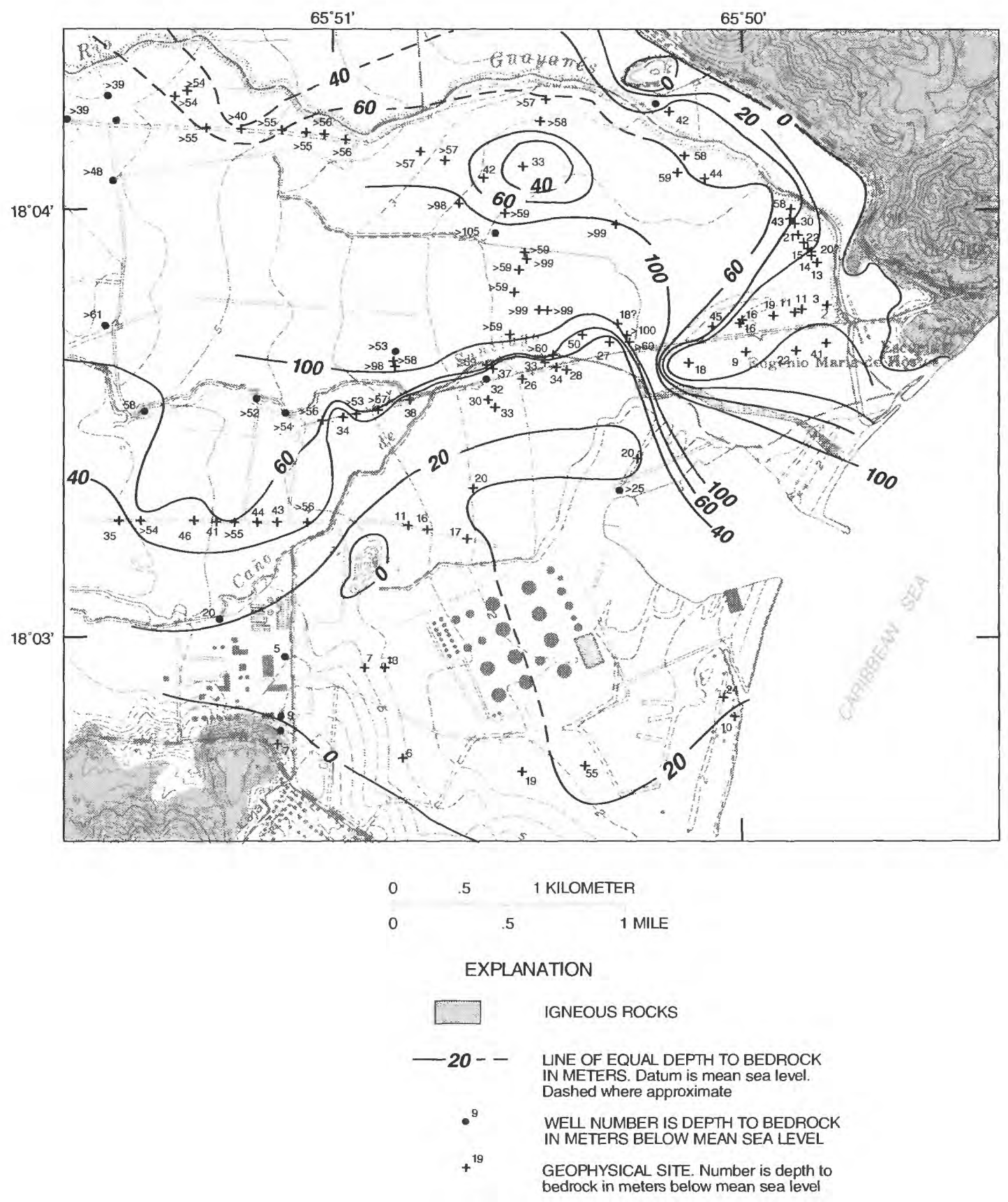

Figure 14. Map of the altitude of the top of bedrock in the Valle de Yabucoa, Puerto Rico (map is based on well data and surface geophysical measurements. 


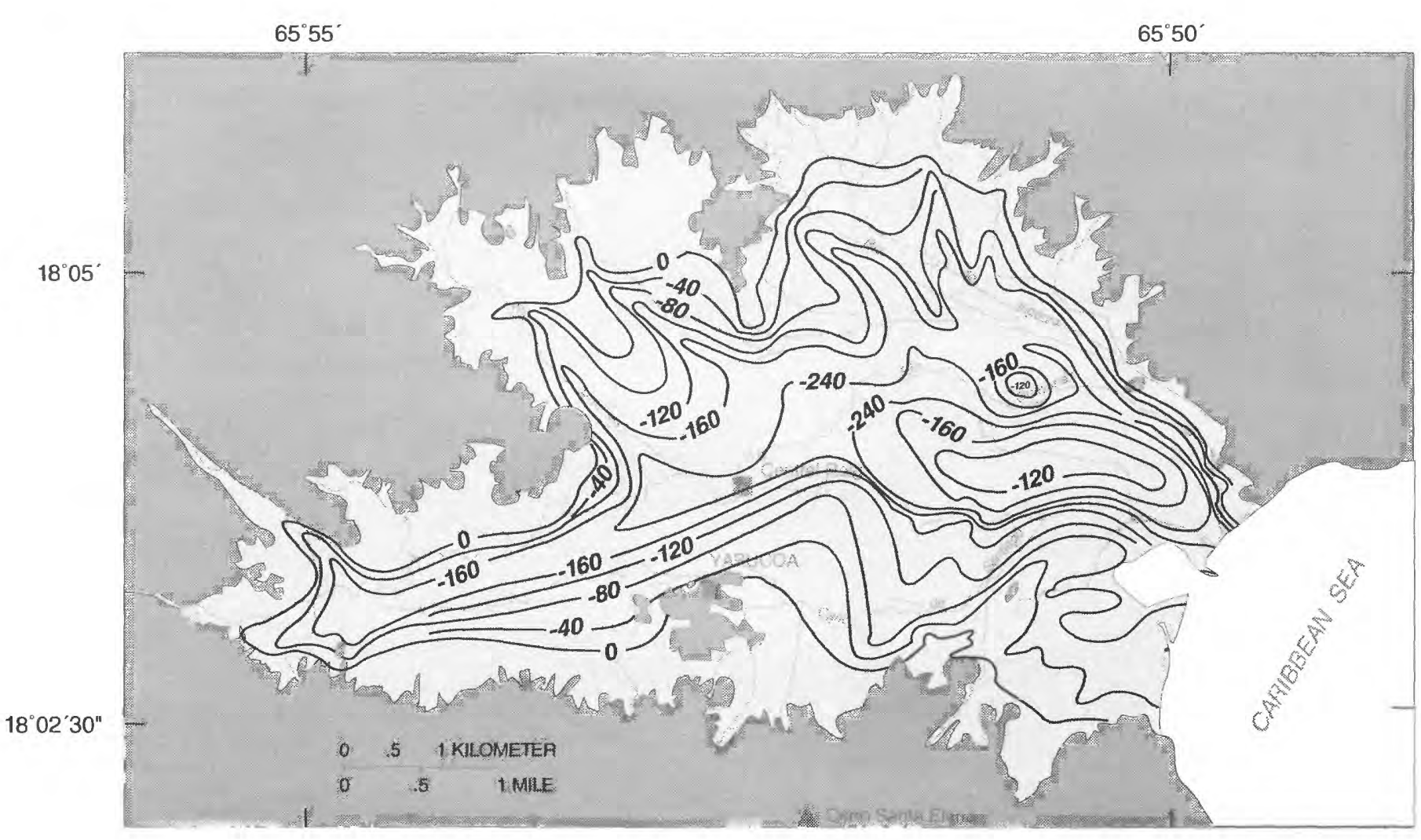

EXPLANATION

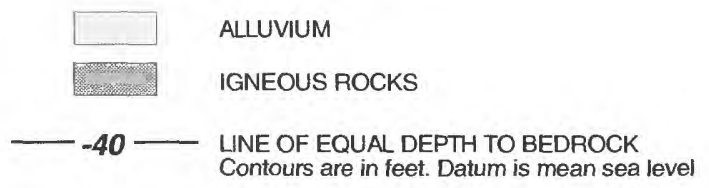

Figure 15. Map of the elevation of the top of bedrock in the Valle de Yabucoa, Puerto Rico (from Robison and Anders, 1973, p. 4) based on the drilling data available in 1970. Contours are in feet below mean sea level.

\section{SUMMARY}

The Valle de Yabucoa alluvial aquifer, in southeastern Puerto Rico, is the municipal and industrial water supply for the town of Yabucoa. The aquifer consists of more than $100 \mathrm{~m}$ of alluvium overlying relatively impermeable bedrock. Water samples collected from the aquifer have iron and manganese concentrations as high as 28 and $3.6 \mathrm{mg} / \mathrm{L}$, respectively. Although the elevated iron and manganese concentrations in the aquifer pose no health threat, they frequently exceed the secondary standards for drinking water. In addition, dissolved solids concentrations in some shallow ground-water samples approach the 500-mg/L secondary drinking water standard for total dissolved solids.

Pumping from the aquifer for industrial use and public supply has lowered the water table to below sea level in some areas and has reversed the natural gradient of the water table towards the ocean. The saline-freshwater interface appears to have migrated landward because of this gradient reversal. A subsequent reduction in pumping has caused the water table to rise and may have stopped the landward migration of saline water.

Two surface electromagnetic geophysical techniques (the terrain conductivity method and the transient electromagnetic method) were used to map depth to bedrock and to determine the position of the saline-freshwater interface. Pumping and the shape of the bedrock-alluvium contact appear to control the extent and location of the saline-freshwater interface. The data indicate that saline-water intrusion is probably confined to the deepest part of the aquifer in a narrow paleochannel incised in the bedrock. 


\section{REFERENCES}

Anand, R.R., and Gilkes, R.J., 1984: Weathering of ilmenite in a lateritic pallid zone: Clays and Clay Minerals, v. 32, n. 5, p. 363-374.

Anders, R.B., 1971, Electrical analog model study of water in the Yabucoa valley, Puerto Rico--Phase 1, collecting preliminary data and assembling available data: U.S. Geological Survey Open-File Report, 47 p.

Ball, J.W., and Nordstrom, D.K., 1991, User's manual for WATEQ4F, with revised thermodynamic data base and test cases for calculation speciation of major, trace, and redox elements in natural waters: U.S. Geological Survey Open-File Report 91-193, 189 p.

Boccheciamp, R.A., 1977, Soil survey of the Humacao area of eastern Puerto Rico: U.S. Department of Agriculture, Soil Conservation Service, 103 p.

Briel, L.I., 1993, Documentation of a multiple-technique computer program for plotting major-ion composition of natural waters: U.S. Geological Survey Open-File Report 93-74, 88 p.

Briggs, R.P., and Akers, J.P., 1965, Hydrogeologic map of Puerto Rico and adjacent islands: U.S. Geological Survey Hydrologic Investigation Atlas HA-197.

Cadilla, J.F., 1963, Geology of the Humacao titaniferous iron deposit: Caribbean Journal of Science, v. 3, no. 4, p. 243-247.

Calvesbert, R.J., 1970, Climate of Puerto Rico and U.S. Virgin Islands, revised: U.S. Environmental Science Services Administration, Climatography of the United States 60-52, $29 \mathrm{p}$.

Collar, P.D., Troester, J.W., Deike, R.G., and Robinson, P.D., 1990, Iron and manganese in alluvial ground water, Yabucoa, Puerto Rico: 22nd Congress of the Interamerican Association of Sanitary and Environmental Engineering, AIDIS, San Juan, Puerto Rico, v. 1, p. 708-732.

Colony, R.J., and Meyerhoff, H.A., 1935, The magnetite deposit near Humacao, Puerto Rico: American Institute of Mining and Metallurgical Engineers Transactions v. 115 , p. 247-272.

Cox, D.P., and Briggs, R.P., 1973, Metallogenic map of Puerto Rico: U.S. Geological Survey Miscellaneous Geological Investigation Map I-721.
Cox, D.P., Marvin, F.F., M'Gonigle, J.W., McIntyre, D.H., and Rogers, C.L., 1977, Potassium-argon geochronology of some metamorphic, igneous, and hydrothermal events in Puerto Rico and the Virgin Islands: U.S. Geological Survey Journal of Research, v. 5 , no. 6 , p. 689-703.

Fairbanks, R.G., 1989, A 17,000-year glacio-eustatic sea level record: influence of glacial melting rates on the Younger Dryas event and deep-ocean circulation: Nature, v. 342, p. 637-642.

Fettke, C.R., 1924a, Geology of the Humacao district, Porto Rico: New York Academy of Science, Scientific Study of Porto Rico and the Virgin Islands, v. 2, pt. 2, p. 117-197.

1924b, Magnetic deposits of eastern Porto Rico: American Institute of Mining and Metallurgical Engineers Transactions, v. 70, p. 1024-1042.

Fields, F.K., 1971, Floods in the Yabucoa area, Puerto Rico: U.S. Geological Survey Hydrologic Investigation Atlas HA-382.

Fishman, M.J., and Friedman, M.J., 1989, Methods for determination of inorganic substances in water and fluvial sediments, $3 \mathrm{~d}$ ed.: Techniques of WaterResources Investigations of the United States Geological Survey, Chapter Al; U.S. Geological Survey Open-File Report, 545 p.

Fitterman, D.V., and Stewart, M.T., 1986 Transient electromagnetic sounding for groundwater: Geophysics, v. 51, p. 995-1005.

Giusti, E.V., and López, M.A., 1967, Climate and streamflow of Puerto Rico: Caribbean Journal of Science, v. 7, p. 87-93.

Guillou, R.B., and Glass, J.J., 1957, A reconnaissance study of the beach sands of Puerto Rico: U.S. Geological Survey Bulletin 1042-I, p. 273-305.

Hem, J.D., 1985: Study and interpretation of the chemical characteristics of natural water ( $3 \mathrm{~d}$ ed.): U.S. Geological Survey Water-Supply Paper 2254, 264 p.

Lobeck, A.K., 1922, The physiography of Porto Rico: New York Academy of Science, Scientific Survey of Porto Rico and the Virgin Islands, v. 1, pt. 4, p. 301379.

Marsh, S.P., 1992a, Analytical results for stream sediment and soil samples from the Commonwealth of Puerto Rico, Isla de Culebra, and Isla de Vieques: U.S. Geological Survey Open-File Report 92-353A, 8 p. 
1992b, Analytical results for stream sediment and soil samples from the Commonwealth of Puerto Rico, Isla de Culebra, and Isla de Vieques: U.S. Geological Survey Open-File Report 92-353B, 5.25inch diskette.

McNeill, J.D., 1980, Electromagnetic terrain conductivity measurement at low induction numbers: Geonics Limited, $15 \mathrm{p}$.

1983, EM34-3 survey interpretation techniques: Geonics Limited, 16 p.

1991, Use of electromagnetic methods for groundwater studies: Geotechnical and Environmental Geophysics: v. 2, p. 191-217.

Meyerhoff, H.A., 1933, Geology of Puerto Rico: Puerto Rico University Monograph, series B, no. 1, 306 p.

M'Gonigle, J.W., 1978, Geologic map of the Humacao quadrangle, Puerto Rico: U.S. Geological Survey Miscellaneous Investigation Map I-1070.

Morad, S., and Aldahan, A.A., 1985: Leucoxene-calcitequartz aggregates in sandstones and the relation to decomposition of sphene: Neues J. für Mineralogie, v. 10, p. $458-468$.

Piper, A.M., 1944, A graphic procedure in the geochemical interpretation of water analyses: American geophysical Union Transactions, v. 25, p. 914-923.

1953, A graphic procedure in the geochemical interpretation of water analyses [revised]: U.S. Geological Survey Ground Water Notes, Geochemistry, no. 12, 14 p.

Plummer, L.N., Parkhurst, D.L, and Thorstenson, D.C., 1983, Development of reaction model for groundwater systems: Geochimica et Cosmochimica Acta, v. 47 , p. $665-686$.

Plummer, L.N., Prestemon, E.C., and Parkhurst, D.L., 1991, An interactive code (NETPATH) for modeling net geochemical reactions along a flow path: U.S. Geological Survey Water-Resources Investigations Report 91-4078, 227 p.

Richards, R.T., and Troester, J.W., 1991, Mapping the saline-freshwater interface and the depth to bedrock in the Valle de Yabucoa alluvial aquifer with surface geophysical techniques: Abstracts and Program for the 17th Symposium of Natural Resources, San Juan, Puerto Rico, November 1991, p. 18-19.
Richards, R.T., and Troester, J.W., 1993, The use of surface geophysics to determine the best location for an observation well to monitor saline-water intrusion the Valle de Yabucoa alluvial aquifer, southeastern Puerto Rico: Advances in Water Resources Research in Puerto Rico and the U.S. Virgin Islands, San Juan, Puerto Rico, p. 38-39.

Robison, T.M., and Anders, R.B., 1973, Electrical analog model study of the alluvial aquifer in the Yabucoa valley, Puerto Rico--Phase 2, The planning, construction, and use of the model: U.S. Geological Survey Open-File Report 73-1, 22 p.

Rogers, C.L., 1977, Geologic map of the Punta Guayanés quadrangle, southeastern Puerto Rico: U.S. Geological Survey Miscellaneous Investigations Series Map I-998.

Rogers, C.L., Cram, C.M., Pease, M.H., Jr., and Tischler, M.S., 1979, Geologic map of the Yabucoa and Punta Tuna quadrangles, Puerto Rico: U.S. Geological Survey Miscellaneous Investigations Series Map I-1086, scale 1:20,000.

Troester, J.W., Collar, P.D., Robinson, P.D., and Deike, R.G., 1990a, Geochemical processes controlling manganese and iron concentrations in the ground water of the Valle de Yabucoa alluvial aquifer, Puerto Rico: EOS, Transactions, American Geophysical Union, v. 71, p. 506.

Troester, J.W., Deike, R.G., Robinson, P.D., and Collar, P.D., 1990b, Petrographic analyses and geochemical modeling of aqueous/solid phase reactions in the Valle de Yabucoa alluvial aquifer, Puerto Rico: Geological Society of America Annual Abstracts and Program, v. 22, no. 7, p. 295.

U.S. House of Representatives, 1996, Secondary maximum contaminant levels: Code of Federal Regulations, Title 40, Chapter I, Subchapter C, Part 143.

U.S. Geological Survey, 1994-96, Water resources data, Puerto Rico and the U.S. Virgin Islands, Water Years 1993-95: U.S. Geological Survey Water-Data Reports PR-93-1 to PR-95-1 (published annually).

Viessman, W., Jr., and Hammer, M.J., 1985: Water supply and pollution control (4th ed.): Harper \& Row, 797 p.

Wood, W.W., 1976: Guidelines for collection and field analysis of ground-water samples for selected unstable constituents: Techniques of WaterResources Investigations of the United States Geological Survey, Book 1, Chapter D2: 24 p. 